\title{
Study of diseases and the immune system of bivalves using molecular biology and genomics
}

\author{
Camino Gestal ${ }^{1}$, Philippe Roch ${ }^{2}$, Tristan Renault ${ }^{3}$, Alberto Pallavicini ${ }^{4}$, Christine \\ Paillard ${ }^{5}$, Beatriz Novoa $^{1}$, Radouane Oubella ${ }^{6}$, Paola Venier ${ }^{7}$, and Antonio
}

Figueras $^{1 *}$

\author{
${ }^{1}$ Instituto Investigaciones Marinas. CSIC. Spanish National Reference Laboratory for Mollusc Diseases, Eduardo \\ Cabello 6, 36208 Vigo, Spain \\ ${ }^{2}$ Equipe Pathogènes et Immunité, CNRS-UM2-IFREMER Ecolag, Université de Montpellier 2, \\ cc 093, Place Eugéne Bataillon 34095 MONTPELLIER-France \\ ${ }^{3}$ IFREMER, Laboratoire de Génétique et Pathologie, 17390 La Tremblade, France \\ ${ }^{4}$ Laboratorio di Genetica, Dipartimento di Biologia,Università di Trieste, P.le Valmaura 9, 34143 Trieste (Italy). \\ ${ }^{5}$ Equipe "Interactions hôtes-pathogènes" Laboratoire des Sciences de l'Environnement Marin UMR CNRS 6539 \\ Institut Universitaire Europeen de la Mer, Technopole Brest-Iroise Place Copernic 29280 PLOUZANE, \\ France \\ ${ }^{6}$ Laboratoire de biologie et d'écologie, Université Catholique de l'Ouest Bretagne-Nord. Campus de la tour \\ d'Auvergne, 22200 Guingamp, France \\ ${ }^{7}$ Dept. Biology, University of Padova, Via Bassi 58/B, 35131 Padova, Italy \\ *Corresponding author.
}

\begin{abstract}
Environmental chemico-physical factors, pathogens and biological interactions constantly affect organism physiology and behaviour. Invertebrates, including bivalve molluscs do not possess acquired immunity. Their defence mechanisms rely on an innate, non-adaptive immune system employing circulating cells and a large variety of molecular effectors. The mechanisms underlying host defence depend on the presence of functional proteins in appropriate quantities, within a crucial time window. These proteins are encoded by genes whose transcription is tightly coordinated by complex programmes of gene expression. Currently available advanced techniques allow the evaluation of this gene expression, expanding our understanding of the behaviour and function of cells and tissues under varying conditions. In particular, the DNA microarray technology is a closed high-throughput method
\end{abstract}


that enables measurement of a large predetermined set of known genes or sequences. Expressed sequence tag sequencing from redundant, normalized, subtractive hybridization libraries has come to the forefront as a robust method for sampling the protein encoding genes that are expressed within a tissue or a particular set of physiological conditions. The elimination of microorganisms by defense cells is a dynamic process that involves integrating synthesis of granule proteins during differentiation, migration onto sites of infection, phagocytosis and killing of microorganisms, modulation of their effector cells and finally apoptosis. Understanding how this complex biological process is regulated can best be addressed by a systems biology approach to the study of organisms and populations, which help researchers more effectively, to decipher the continuous challenge between two genomes, i.e. evolving host-pathogen interactions.

Key words: bivalve, diseases, contaminants, stress, immune defense, gene expression, genomic approach.

\section{INTRODUCTION}

Bivalve culture is steadily growing in importance in the aquaculture sector. However, from time to time, populations of cultivated molluscs, mainly oysters, mussels, and clams, suffer from severe mortalities. Among the possible causes is the occurrence of several diseases due to a wide variety of pathogens. Such pathogens belong to all the phyla including viruses (Irido-like, Herpes-like virus, Papovaviridae, Togaviridae, Retroviridae, Reoviridae, Birnaviridae and Picornaviridae), bacteria (Vibrio tapetis, Vibrio spp., Nocardia), protozoan (species of the genera Marteilia, Bonamia, Perkinsus, Mycrocytos) and metazoan parasites (the copepode Mytilicola among others) (reviewed by Bower et al., 1994). A general view of the most important pathogenic agents is depicted in the next section. Protozoan pathogens are the most frequently described disease agents among molluscs. 
Some of the factors that may facilitate development of diseases in cultured molluscs include: (i) increases in population density that increases the risk of healthy animals encountering a sick animal, facilitating disease transmission, (ii) increases in animal transfer frequency, (iii) weakening of animals under stress, (iv) diversity in host genetic and immune-competency and (v) diversity in pathogen virulence. The first three may be fully or partially controlled by adjusting management practices, while more basic knowledge is needed to effectively modulate the impact of the third. In addition, knowledge of the biology and genetics of pathogens as well as the host is essential. Precise identification of pathogens (taxonomy) and specific diagnostic tools are needed. Approaches based on molecular biology and biotechnology can be used to obtain such results.

Since infectious diseases remain a major concern for aquaculture and may result in massive losses, and sometimes can entirely shutdown a particular operation, management of infectious diseases is a priority for aquaculture sustainability. However, molluscs, including bivalves, are unique in terms of health management. There are few tools to control and reduce the impact of pathogen agents. Molluscs are invertebrates lacking a specific immune response and immunological memory and therefore they rely totally on their innate immune systems to overcome diseases. As molluscs do not possess lymphocytes and do not produce antibodies, vaccination cannot be used to protect them against infectious diseases. Moreover, the preventive or therapeutical use of drugs is highly restricted since mollusc farming is carried out in the natural marine environment.

The innate immune system of invertebrates employs circulating cells and a large variety of molecular effectors. Originally, innate and adaptive immunity were considered as two independent mechanisms. At present, they appear to be more intricately linked with the innate immunity playing a key role in stimulating the subsequent clone response of adaptive immunity (Fearon and Locksley, 1996; Hoffmann et al., 1999). New discoveries, such are 
gene rearrangement mechanisms in lampreys and somatic hyper mutation/alternative splicing in molluscs, have meant that a reconsideration of our fundamental views is now essential (Flajnik and Du Pasquier, 2004; Vivier and Malissen, 2005).

Invertebrate cellular defence relies primarily on the hemocytes through infiltration, aggregation, encapsulation, cytotoxic reactions and phagocytosis of foreign particles. Several biologically active molecules have been reported in the hemolymph of bivalve molluscs. They are generally classified into two categories: serologically active (opsonins, lysins, agglutinins, antimicrobial factors, lysozymes) and enzymes of lysosomal origin (aminopeptidases, $\beta$ glucuronidases, acid phosphatase, alcalin phosphatase, $\alpha$-mannosidase, esterases and peroxidases). The precise molecular mechanism of action is known for only some humoral factors, despite their important role as bacteriolytic and bacteriostatic agents (Canicatti and Roch, 1993).

\section{Stress and response to stress in bivalves}

2.1 Biological costs of adverse environmental changes. Chemico-physical factors and biological interactions constantly affect organism physiology and behaviour. Conversely, the organism response to external changes disrupting functional homeostasis depends on the genetic uniqueness of individuals and populations, namely gene pools, allelic patterns and finely tuned gene expression.

In the complex frame of gene-environment interactions, the mechanisms of physiological reactions and genetic adaptation well depict the stress response, i.e. the cascade of events triggered by external stressors and pushing a given species beyond the limits of its environmental niche (van Straalen and Roelofs, 2006). Some of the earlier effects induced by stress on an organism may include physiological adjustments which are often transient and also relate to behavioural reactions and recovery from structural damage. In addition to the 
immediate value closure induced by mechanical or chemical stress, changes in water coverage influence the overall metabolism and individual growth rates of bivalve species (Ortmann and Grieshaber, 2003; Bishop and Peterson, 2006). Long-term consequences depend on the persistence of the adverse conditions (thermal, chemical, climatic and biotic changes) and are primarily driven by genotype selection, ultimately prevailing on the effects of mutation, migration and stochasticity (Nevo, 2001). Taken together, the changes that occur in a given species or population over a particular space/time scale define specific adaptive stress syndromes. For example, marine species such as mussels rarely develop tumors as a stress response to genotoxic pollutants, and therefore Kurelec (1993) defined the term 'genotoxic disease syndrome' to indicate the functional impairment resulting from reduced enzyme function, altered protein turnover and metabolism, inhibition of growth, degenerative processes, faster ageing, increased frequency of diseases, impairment of reproduction, adaptation and survival.

Consistent with adaptation and speciation, geographical differences in stress susceptibility have been reported in the Mytilus species complex (Riginos and Cunningham, 2005) and, on a regional scale, xenobiotic-induced oxidative stress was found to be inversely related to a natural salinity gradient (Prevodnik et al. 2007). In juvenile Pacific oysters, Crassostrea gigas, genetic variability at loci related to energy production and immune function was found to be one of the major determinants of sensitivity to summer mortality, a phenomenon emerging from complex interactions between host, pathogens and environmental factors (Huvet et al., 2004).

In essence, the concerted pressure of different stressors including salinity, temperature, chemical pollutants and potential pathogens can disrupt functional homeostasis, define irreversible alterations and set the basis for genetic adaptation (Reid et al., 2003; Paillard et al., 2004b; Parry and Pipe, 2004). 
A general problem in obtaining a better understanding of the stress response in bivalves is the complete lack, or fragmentary nature of our knowledge on their genes, proteins and regulatory networks. At the moment, three species have been selected for genome sequencing: the bay scallop Argopecten irradians, the eastern oyster C. virginica and the surf clam Spisula solidissima (NCBI browsed at March 2007: project ID 13038, 12979 and 12959, respectively). A fourth project launched by DOE Joint Genome Institute refers to the mussel Mytilus californianus (http://www.jgi.doe.gov). Their genome approximately spans from $0.67 \times 10^{9}$ bp of $C$. virginica to $1.57-1.88 \times 10^{9}$ bp of $M$. californianus (http://www.genomesize.com) but only 50 to 774 redundant protein sequences are currently available per species (the lower and upper limits refer to S. solidissima and M. californianus, 827 are listed for $M$. edulis).

On the other hand, up to several thousands of redundant nucleotide records are present in GenBank and cDNA microarrays of about $1.7 \mathrm{~K}$ and $6.8 \mathrm{~K}$ size have made available for mussels and oysters, respectively (Cunningham et al., 2006; Venier et al., 2006; Jenny et al., 2007). Also, gene expression analysis based on megacloning and Massive Parallel Signature Sequencing has Bearing in mind the early appearance and maintenance of defence systems been used to investigate larval growth heterosis in C. gigas (Hedgecock et al., 2007). Such innovative approach indicated that a relatively small number of candidate genes $(\sim 350$ of $>20000$ transcripts) leads the variation in body size and essential functioning in oyster larvae.against common stressors throughout evolution, the genes involved in the bivalve stress response should broadly encompass signalling pathways, cell cycle regulation, protein turnover, detoxification mechanisms and immune functions. Depending on the particular stressor involved, as well as the traits and life stage of the sepecies affected, the specific sets of genes responding to adverse environmental changes offer unique molecular signatures, i.e. 
gene expression profiles and proteomes. A general view of the bivalve responses to abiotic factors, toxicants and potential pathogens is outlined below.

2.1.1. Responses to abiotic stress. Intertidal and shallow-water bivalves experience large fluctuations in environmental physico-chemical factors, for instance the so called aestivation and periodic anhydrobiosis. Mytilidae and other bivalves are facultative anaerobes and react to cyclic or prolonged hypoxia, cold temperatures and low salinity by isolating themselves from the external environment, reducing all the energetic processes and switching to anaerobic metabolism (De Zwann and Mathieu, 1991; Ortmann and Grieshaber, 2003).

During functional or environmental anaerobiosis, bivalves consume primarily carbohydrates, to support cellular ATP levels, and generate end-products such as alanine, alanopine, succinate, and propionate. In particular, D-alanine can be regarded as one of the major intracellular osmolytes as it significantly increases in tissues of bivalves and crustaceans under salinity stress (Abe et al., 2005). Tolerance to intermittent hypoxia/ anoxia in mussels probably results from the glycolitic depression mediated by cyclic GMP and 6-phosphofructo-1-kinase (Diaz-Enrich et al., 2002).

Genes transcripts in different physiological pathways have been identified by suppression subtractive hybridisation (SSH) in C. gigas during experimental hypoxia (David et al., 2005). Enhanced expression of the genes encoding metallothionein and MXR (multixenobiotic resistance) proteins was observed in the freshwater clam Corbicula fluminea subjected to cadmium and hypoxia stresses (Legeay et al., 2005). In addition, up-regulation of proteins related to oxidative stress was evident in the surf clam Donax variabilis in response to hypoxia, hyperoxia and hydrogen sulfide (Joyner-Matos et al., 2006).

Heat shock proteins are almost ubiquitous in living organisms and play a key role in the cellular stress response. They act as protein chaperones in normal development and in 
response to various thermal and chemical stressors, stabilizing signalling-related proteins and assisting protein folding, unfolding and degradation. During organism development, hsp90 influences the morphogenetic pathways, channelling phenotypic variation in spite of destabilizing stochastic events (Rutherford et al., 2007). Following thermal and chemical stress, different levels of hsp70 isoforms, hsp60, and hsp90 have been observed in the mussel Mytilus galloprovincialis and abalone Haliotis rufescens (Snyder et al., 2001). Species- and tissue-specificity of heat-shock response, and cross-protection against toxicant-induced stress, has been reported in bivalves (Piano et al., 2004). Relevant to further investigations, the small hsp27 gene appeared significantly down-regulated in the digestive gland of mussels exposed to toxicant cocktails in both experimental and field conditions (Venier et al., 2006). Conversely, acute cold stress can rapidly alter opiate signalling and gill ciliary activity in mussels by inhibiting the expression of opiate receptor transcripts and constitutive nitric oxide release (Cadet et al., 2002). As reported in the periwinkle Littorina littorea, cold and anoxia were shown to modulate mitogen-activated protein kinases activity and resulted in metallothionein induction in these bivalve tissues (MacDonald and Storey, 2006).

2.1.2. Responses to toxicant stress. Environmental pollutants differ greatly in their physicochemical properties, bioavailability and potential toxicity for organisms with diverse life traits and reproductive strategies, the most potent toxicants impairing biological functions at low or very low doses. According to the Mussel Watch concept, the measurement of structural and functional alterations at an early stage of induction by toxic chemicals provides the rational for coastal pollution biomonitoring (Goldberg and Bertine, 2000).

Toxicants with various chemical structures are electrophilic and generate reactive oxygen and nitrogen species (e.g. superoxide anion radical $\mathrm{O}_{2}{ }^{{ }^{-}}$, hydrogen peroxide $\mathrm{H}_{2} \mathrm{O}_{2}$, peroxyl radicals ROO', nitrogen oxide radical NO*). Exposure to metals, polycyclic aromatic hydrocarbons, organochlorine and organophosphate pesticides, polychlorinated biphenyls, 
dioxins, and other xenobiotics can increase the physiological levels of such reactive species, define oxidative stress and disrupt vital processes in living organisms (Valavanidis et al., 2006). Transition metals, quinones, some pesticides and other compounds can undergo to redox cycling and consequently enhance the oxidative stress (Canova et al., 1998). Nonenzymatic defences include vitamins such as tocopherols and ascorbate, thiols as glutathione and other scavenging molecules (Blair, 2006). Superoxide dismutase, GSH peroxidases, reductases and catalase enzymes activity has been measured in bivalve tissues to evaluate oxidative stress (Valavanidis et al., 2006). Following endogenous and exogenous oxidative DNA damage, specific repair pathways conserved through evolution can recover oxidized bases (e.g. 8-oxodG, thymine glycol), apurinic sites and strand breaks (Bohr, 2002). Data from mammalian studies suggest that cell and tisuue homeostasis is supported by a network of circadian proteins that support cell and tissue homeostasis, not only in normal physiology, but also during the genotoxic stress response (Kondratov et al., 2007). Evidence for antioxidant responsive element (ARE)-dependent gene expression in mammalian tissues suggests the robustness of signalling pathways and protein networks activated against the oxidative stress (Zhang, 2006). Nevertheless, specific and detailed knowledge of how these molecular mechanisms act in bivalves is still scarce. In the digestive gland and gills of M. edulis, acute oxidative stress causes protein carbonylation, high ubiquitin levels and modest changes in glutathione transferase, glucose 6-phosphate dehydrogenase and glutathione reductase activity (McDonagh and Sheehan, 2006). According to the Comet assay Cerastoderma edule and $M$. edulis displayed different sensitivity to DNA damage (Cheung et al., 2006) with indirect evidence of DNA repair (Emmanouil et al., 2007).

Metallothioneins (MTs) are other group of molecules chiefly involved in the response to oxidative stress, especially from toxic metals. They are low-molecular-weight, cysteine-rich peptides, displaying oxyradical scavenging activity and high affinity for free metal ions such 
as $\mathrm{Zn}, \mathrm{Cd}, \mathrm{Cu}$ and $\mathrm{Hg}$,and thereby causing metal sequestration and detoxification. In response to anoxia and oxidative stress, transcription of MTs commonly occurs by trans-activation of metal-response promoter elements (Bourdineaud et al., 2006). Three MT isoforms are known in C. gigas (Tanguy et al., 2001) and the high frequency of two polymorphic variants of CgMT1 has been suggested as an explanation of oyster tolerance to metals in experimental and field populations (Tanguy et al., 2002). At least one MT isoform exists in the fresh water zebra mussel Dreissena polymorpha whereas in Mytilus species two main isoforms (MT10 and MT20) with tissue-specific levels of constitutive and induced expression have been identified (Vergani et al., 2005).

In addition to MTs, the endo-lysosomal vesicle system contributes to the sequestration of excessive amounts of metals and organic xenobiotics with time-dependent changes in lysosomal size and integrity (Marigomez et al., 2005). Particularly in the digestive gland of filter-feeding bivalves, effective bioaccumulation coupled to low levels of biotransformations explains the resulting toxicant overload and related cellular damage (Canova et al., 1998).

Compared to fish and mammals, competence for phase I - biotransformations (functionalization of xenobiotic molecules) is limited in bivalves, with active (FADdependent) monoxygenation of aromatic amines and limited monoxygenation of polycyclic aromatic compounds (Kurelec and Gupta, 1993; Boutet et al., 2004a). The existence of CYP4 isoform has been reported in M. galloprovincialis but the expression and AhR-mediated inducibility of cytochrome P450-like proteins in bivalves require further study (Chaty et al., 2004). Among the phase II conjugating enzymes (conjugation to endogenous substrates), gene expression of glutathione S-transferase (GST) has been studied in various bivalves (Doyen et al., 2005; Myrnes and Nilsen, 2007). The substantial gene expression of GST in mussel gills, the first target tissue of water contaminants, confirms the detoxifying role of glutathione and GST. 
The cellular response to endocrine disrupting compounds (EDCs) is more difficult to outline due to the multiplicity of suspected chemicals and variety of adverse effects (Yang et al., 2006). In addition to natural ligands such as $17 \beta$-estradiol, alkylphenols and other environmental contaminants can bind the cytoplasmatic estrogen receptor in sensitive cell types and lead to the transcriptional activation of many genes. Mimicking or counteracting the natural hormones, EDCs can affect the reproductive and developmental processes of vertebrate species, humans included. In Nucella spp. and many other gastropods, exposure to low levels of organotin compounds has been causally associated to the imposex condition, female sterility and severe population decline (Plejdrup et al., 2006). Steroidogenic pathways and possible markers of endocrine disruption in marine bivalve molluscs are under investigation (Porte et al., 2006; Wintermyer and Cooper, 2007). Undoubtedly, approaches using functional genomics approaches will be able to provide valuable information on the EDC stress response as it involves complex signalling pathways and wide-ranging changes in gene expression.

\section{Genomic of molluscan pathogens}

For many pathogens of molluscs, current diagnostic techniques are rather limited, and screening has been restricted to histological and ultrastructural examination. Protozoans are the most studied mollusc pathogens (Table1). Molecular techniques for detecting and identifying pathogens in molluscs are been developed as validate and as suitable tools and are expected to be increasingly used in pathogen monitoring programmes (Figueras and Novoa, 2004). International standards proposed by the OIE include molecular techniques for the detection and identification of listed pathogens (OIE 2006). The routine use of DNA-based diagnostic tools is however hampered by a number of major concerns. Not all regions of the pathogen DNA are equally useful as targets for molecular detection. Closely 
related pathogens may present high sequence similarities. Moreover, molecular tools detect DNA and not necessarily a viable pathogen. The assays often have not been thoroughly tested for inclusivity (detection of all strains of the pathogen) or specificity (cross reaction with any other organism). A main concern is that molecular tools too often are developed from a few sequences without a good understanding of the overall sequence variability within the species. Finally, PCR - despite its sensitivity - is still subject to the same problems that other diagnostic methods are: the tiny piece of tissue used for amplification may simply not contain the pathogen.

Although taxonomy of mollusc pathogens is still unsettled, DNA sequencing has shed new light on pathogen classification. In this context, DNA probes for mollusc pathogens have been most often designed from genes used for phylogenetic studies which frequently do not reflect the huge diversity in terms of virulence. There is a growing recognition of the need for strain differentiation in diagnostic procedures.

Moreover, molecular tools need formal validation against traditional techniques and testing for their specificity. Studies conducted in parallel with the same isolates in several laboratories would be ideal. It will also be necessary to identify regions of the pathogen genome that can be utilised for species differentiation. Moreover, all molecular assays specific for a pathogen should be tested in parallel and validated, and further sensitive diagnostic assays that will clearly discriminate between all "valid" species should be developed. To confirm the presence of a pathogen, molecular approaches should be used in conjunction with other methods including histology in order to allow pathogen visualization. Different approaches need to be used in term of diagnosis including information on susceptible host species and disease pattern, detection and molecular characterisation. 
3.1. Viral diseases. Among the various viruses detected in bivalves, herpes-like viruses has been the most studied at the molecular level. Herpes-like virus infections have been identified in several marine mollusc species in different countries including the USA, New Zealand, France, Australia and Mexico (Friedman et al., 2005; Renault and Arzul, 2001). The purification of herpes-like viral particles from C. gigas larvae allowed the extraction of the viral DNA (Le Deuff and Renault, 1999), the genome was completely sequenced and its overall structure has been determined (Davison et al 2005). Extraction and sequencing of Ostreid Herpes virus 1 (OsHV-1) DNA from purified particles infecting C. gigas larvae (Le Deuff and Renault, 1999) facilitated the development of molecular diagnostic tools. A PCRbased procedure for detecting the herpesvirus that infects the Pacific oyster, C. gigas, in France was first developed by Renault et al., in 2000. Since that time, several PCR diagnostic protocols have then been developed (Renault et al. 2000; Arzul et al., 2002; Friedman et al., 2005). Various primer pairs (Arzul et al., 2001; Renault and Arzul, 2001; Barbosa-Solomieu et al., 2004) have been designed and used to detect viral DNA using either one-round or nested PCR. In addition, the PCR conditions used for detection of OsHV-1 also allow the amplification of DNA from other close related herpesvirus as it was the case of a variant of OsHV-1 (Arzul et al., 2001; Friedman et al., 2005). Despite the various methods that have been developed for the diagnosis of bivalve herpesvirus by PCR, it is noteworthy that the specificity was tested using DNA from vertebrate herpesvirus since at the time of the development, OsHV-1 was the only known herpesvirus infecting invertebrates (Davison et al., 2005). Therefore, it should be noted that the PCR assay may need to be redesigned of additional invertebrate herpesviruses are found in the marine environment. At this time the analysis of the same samples with different primer pairsis been used to evaluate the diagnostic specificity of the primer pairs. Another technique that has also been developed is in situ hybridisation (ISH) that allows the detection and visualization of viral DNA on histological 
sections using a labelled DNA probe (Lipart and Renault, 2002; Barbosa-Solomieu et al., 2004)

3.2. Bacterial diseases. Molecular detection methods have recently been developed for the identification of several bacteria species which infect molluscs including Vibrio tapetis, Roseovarius crassostreae and Vibrio aestuarianus. The aetiological agent of brown ring disease, $V$. tapetis, can be identified using dot blot hybridisation and a species-specific primer assay (SSP-PCR) (Paillard et al., 2006). Maloy et al. (2005) have also developed a PCR technique for identification of the aetiological agent of juvenile oyster disease (JOD), $R$. crassostreae.

Although PCR techniques can provide molecular identification of specific bacterial pathogens, bacterial strains belonging to the same species may differ in virulence level (i.e. $V$. splendidus) and therefore techniques that allow strains to be distinguished can be useful. Strain genotyping appears a suitable tool in order to better associate a specific genetic type to disease. DNA typing may be carried out using different techniques targeting intergenic rDNA spacer regions, individual genes, a gene cluster and the whole genome. Stains presenting different levels of virulence can be observed for a same bacterial species. In this context, molecular diagnostic techniques targeting some virulence factors appear as the most adapted tools. Morover the virulence characterisation needs also experimental trials in order to confirm if a particular strain is virulent or not trials.

Vibrios are ubiquitous in aquatic ecosystems. Vibrio strains influence the health of cultured marine organisms and constitute pathogens or potential pathogens. Vibrio splendidus-related species have been reported in association with mortality outbreaks of molluscs (Lacoste et al., 2001b; Gómez-León et al., 2005). Epidemiological studies indicate high genetic diversity in this group suggesting a polyphyletic nature (Le Roux et al., 2005). DNA gyrase subunit B $($ gyrB) gene sequencing has been used to characterise $V$. splendidus-related isolates from 
oysters (Le Roux et al., 2005) and although several strains clustered together, they could not be assigned to any known Vibrio species. In this context, taxonomic analysis of unidentified isolates based on a polyphasic approach including gene sequencing, fluorescent amplifiedfragment length polymorphism (FAFLP) fingerprinting, DNA-DNA hybridisation and biochemical tests has successfully been used by several authors to define new species (Thompson et al., 2003; Le Roux et al., 2005).

3.3. Bonamiosis. The detection of dense cytoplasmic structures called haplosporosmes in microcell parasites (i.e. Bonamia ostreae, B. exitiosa, Mikrocytos roughleyi, M. mackini) suggested that these parasites belong to the phylum Haplosporidia whose members are defined by their spores (Sprague, 1979). However, spores have never been detected in microcell parasites including $B$. ostreae. In this context, these parasites have previously not been assigned with certainty to any group. The recent use of molecular phylogenetic analyses (Carnegie et al., 2000, Cochennec et al., 2000; Reece and Stokes, 2003; Reece et al., 2004) allowed the inclusion of the genus Bonamia in the phylum Haplosporidia. Sequencing of the SSU rRNA and actin genes in Bonamia ostreae, B. exitiosa and M. roughleyi demonstrated that species of Bonamia constitute a monophyletic clade within the haplosporidian, as sister taxa to Minchinia spp. However, M. mackini is not related to Bonamia and it is not a member of the Haplosporidia (Hine et al., 2001; Carnegie et al., 2003). As a result, the genus Mikrocytos was found to be polyphyletic and M. roughleyi was reassigned to the genus Bonamia (Cochennec-Laureau et al. 2003; Reece et al., 2004).

The first DNA-based diagnostic assay for a microcell was designed for B. roughleyi (Adlard and Lester, 1995). Subsequently, a "Bonamia ostreae-specific" PCR assays targeting the SSU rDNA were then developed by Carnegie et al. (2000) and Cochennec et al. (2000). Finally, PCR-restriction fragment length polymorphism (PCR-RFLP) assays could provide the most useful molecular tool to distinguish $B$. ostreae from $B$. existiosa and to distinguish $B$. 
roughleyi from the other Bonamia spp. (Hine et al., 2001; Cochennec-Laureau et al., 2003). The sequence of the SSU rDNA gene of $B$. ostreae shows polymorphism with that of $B$. exitiosa or B. roughleyi by RFLP analysis (Hine et al., 2001; Cochennec-Laureau et al., 2003).

To confirm the presence of a viable pathogen, molecular approaches should be used in conjunction with histology in order to allow pathogen visualization and also validate new diagnostic methods. Two ISH protocols, not yet validated against classical histological techniques, have been developed (Carnegie et al. 2003; Cochennec et al., 2000). PCR and fluorescent in situ hybridisation (HIS) assays for M. mackini were also defined (Carnegie et al., 2003). Recently, Balseiro et al. (2006) have conducted a comparative study demonstrating that molecualr techniques showed higher sensitivity than classical cytological and histological methods. In addition, transmission electron microscopy and PCR-RFLP and sequence analyses are also recommended for a confirmatory diagnosis.

3.4. Haplosporidosis. For the haplosporidian pathogens, the first molecular diagnostic tools were developed for detecting Haplosporidium nelsoni, the causative agent of MSX disease in the eastern oyster. Small subunit rRNA gene sequence was targeted by DNA probes and PCR primers (Stokes and Burreson 1995; Stokes et al. 1995; Day et al., 2000; Penna et al., 2001). Although light microscopy is well suited to detect haplosporidian parasites on histological sections, this technique does not allow discrimination among the plasmodial stages of the various different species. Parasite location, host species and morphological features can be used to help in differential diagnosis. However, in the absence of spores differential diagnosis between $H$. nelsoni and H. costale is problematic. In this context, Stokes and Burreson (2001) developed PCR primers targeting the SSU rRNA gene of these two different Haplosporidium species and were able to show that these diagnostic tools differentally diagnosed $H$. nelsoni and $H$. costale. Moreover, both parasite species can be detected in the same animals 
indicating the occurrence of mixed infections (Stokes and Burreson, 2001). Haplosporidian parasites have also been detected in clams ( $R$. decussatus), and molecular studies revealed that they were related to Urosporidum group (Novoa et al., 2004).

3.5. Marteilisosis. Traditional detection and identification of Marteilia species is based in host specificity, histology, analysis of ultrastructural characters by transmission electron microscopy (Comps et al., 1982; Perkins 1976) and in situ hybridization using specific probes in histological sections (Kleeman et al., 2002; Itoh et al., 2003). However, in certain cases, much controversy has arisen. In Europe $M$. refringens has been detected in oysters Ostrea edulis (Grizel et al., 1974) and mussels Mytilus edulis and M. galloprovincialis (Tigé and Rabouin 1976; Villalba et al., 1993). Another species, M. maurini was described in $M$. galloprovincialis from the Venice Lagoon, Italy (Comps et al., 1982), and in M. edulis from France (Auffret and Poder, 1983). The DNA sequencing and specifically the analysis of the small subunit ribosomal genes (SSU rRNA) of Marteilia purified form infected oysters $(O$. edulis) and mussels (M. edulis) showed identical sequences (Berthe et al., 2000). However, the investigation of the existence of polymorphisms in the internal transcribed spacer region (ITS-1) of the rRNA genes allowed the identification of two Marteilia genetic types in european waters, named "O" and "M", which appeared to be linked to the host species, oyster and mussels, respectively (Le Roux et al., 2001).

Since these results were published, however, other studies found no strict correlation of Marteilia types to mussels or oysters. Recently, Novoa et al. (2005) identified by PCR-RFLP two different restriction profiles in Spain corresponding with the previously referred "O" and "M" types, and a third ITS-RFLP profile was also found. Thus, although there were two distinct evolutionary lineages that corresponded with the "M" and "O" types, phylogenetic analysis showed that some "O" types have switched to " $\mathrm{M}$ " type, and vice versa. Moreover, "O" types were found in mussels and " $\mathrm{M}$ " types were found in oysters, suggesting several 
cross-species transmission of Marteilia between mussels and oysters, and also indicating that the two identified genetic Marteilia groups are not strongly related to the host species.

3.6. Perkinsosis. After the description of the type species Perkinsus marinus, the phylogenetic position of the genus has been subjected to considerable debate and confusion. The use of molecular techniques and DNA sequencing allowed the analysis of its taxonomic position. A review of Perkinsiosis has been published recently by Villalba et al., 2004. Phylogenetic analysis with the SSU rRNA gene sequence suggested that Perkinsus species are more closely related to dinoflagellates than apicomplexan, within the group of Alveolates (Cavalier-Smith, 1993). New molecular evidence suggests that Perkinsus is in fact a dinoflagellate (Siddall et al., 1997; Reece et al., 1997; Saldarriaga et al., 2003; Reece et al., 2004). Based on molecular data, P. olseni and P. atlanticus were recently determined to be synonymous species, with P. olseni having taxonomic priority (Murell et al., 2002). Perkinsus chesapeaki and P. andrewsi, two species described from clams in the mid-Atlantic of the USA, were also found to be the same species (Burreson et al., 2005).

Traditionally, Perkinsus infections have been diagnosed by histopathology or incubating molluscan tissues in Ray's Fluid Thioglycollate medium (RFTM). Molecular techniques, however, have demonstrated that the hypnospores detected by RFTM can belong to other protozoan species, and although being a valid method for routine monitoring for the presence of Perkinsus, it is not a Perkinsus-specific diagnostic tool (Novoa et al., 2002). In addition, molecular methods based on PCR have been developed using appropriate genetic markers, species and strain-specific PCR-based assays. Sequences of the 18S rRNA gene, the ITS and non-transcribed spacers (NTS) regions of the rRNA gene complex have been targered by molecular diagnostics for detection and identification of Perkinsus species. Recently, species and strain-specific PCR-based assays have been developed for the detection of P. marinus (Marsh et al., 1995; Robledo et al., 1999; Yarnal et al., 2000), P. olseni (De la Herrán et al., 
2000; Robledo et al., 2000; Casas et al., 2002), P. andrewsi (Coss et al., 2001) and P. mediterraneus (Casas et al., 2004). In addition to species-specific assays, some Perkinsus genus-specific assays have been developed by PCR (Robledo et al., 2002) and by PCR-RFLP (Abollo et al., 2006). Other PCR-assays have been used for the diagnosis of Perkinsus spp. and Perkinsus-like species (Kotob et al., 1999; Figueras et al., 2000). Immunological detection of Perkinsus using ELISA (Dungan et al., 1997) and PCR-ELISA (Elandalloussi et al., 2004) assays have been also developed.

\section{Response to Disease in Bivalves}

4.1. Phagocytosis. When a pathogen invades a host, multiple reactions occur, initiated both by the pathogen in an attempt to survive and by the host in an attempt to eliminate the invader. In all metazoans, the immune system plays a fundamental role in preventing pathogenic infections and maintaining homeostasis. For more than a century, phagocytosis has been recognized as an important phenomenon shared by all animals, involved not only in nutrition, but also in defence (Silverstein, 1995). Phagocytosis is the primordial mechanism for the elimination of invading micro-organisms and foreign particles in bivalve molluscs. Its purpose is to eliminate all foreign materials including inorganic particles, living organisms (pathogenic or non- pathogenic), as well as modified self-cells. To achieve this goal, sophisticated cascades of reactions involving multiple molecular partners take place (reviewed by Stuart and Ezekowitz, 2005). Laboratory experiments have demonstrated that phagocytosis in bivalve molluscs can be enhanced by short term exposure to low level of xenobiotics (Coles et al., 1995) or lowered by higher concentrations or longer term exposure (Anderson et al., 1981) and pathogens (Ordás et al., 1999). In fact, microbial killing resulted from the combined actions of the phagocytic process along with several humoral defence factors, with such activity varying according to seasons (reviewed by Canesi et al., 2002). Not 
only hemocytes from adult Mytilus edulis, but also from larval stages are capable of phagocytosed, as demonstrated by studies with disaggregated veliger larvae (Dyrynda et al., 1995).

4.2. Respiratory burst and free radicals. Molluscan hemocytes respond to appropriate stimuli with a burst of respiratory activity in a manner resembling the respiratory burst of mammalian phagocytes. The mechanisms involved in the intracellular killing of the phagocytised material result in the generation of various free radicals including reactive oxygen intermediates (ROIs) in the scallops Patinopecten yessoensis and Pecten maximus, the oysters Crassostrea virginica, C. gigas, and Ostrea edulis (Bachère et al., 1991), the mussels M. edulis and M. galloprovincialis (Pipe, 1992) and the clams Mercenaria mercenaria (Buggé et al, 2007). Surprisingly, other clams including Ruditapes decussatus, Mya arenaria and Scrobicularia plana do not possess detectable stimulation of ROI production coupled with phagocytosis (Lopez et al., 1994; Anderson, 1994; Wootton and Pipe, 2003). According to some authors, the protozoan parasite, Perkinsus marinus, may either increase or suppress the production of ROIs in C. virginica (Volety and Chu, 1995). A large production of ROIs obtained with intact but killed $P$. marinus, suggests that there is an active mechanism whereby the living parasite to prevent triggering of this defence mechanism in the host (Anderson, 2001). In addition, even if the molecular mechanism is not elucidated, it is hypothesized that at least some pathogens do not trigger ROIs production, including the protozoan Bonamia ostrea in the oysters C. gigas and O. edulis, the Perkinsus-like parasites and bacteria Vibrio tapetis in M. galloprovincialis (Ordás et al., 2000), several pathogenic Vibrios in C. gigas and the scallop P. maximus (Lambert and Nicolas, 1998) and Vibrio anguillarum in the oyster $C$. virginica (Bramble and Anderson, 1997). Down-regulation of ROI production by noradrenalin suggested that $\beta$-adrenergic receptors are present at the surface of oyster $C$. 
gigas hemocytes (Lacoste et al., 2001a). Some vibrios such as $V$. tapetis was shown to inhibit ROIs production in hemocytes of C. gigas (Lambert et al, 2003).

4.3. Nitric oxide (NO) and derivatives. In vertebrates, nitric oxide (NO) is an important molecule involved in normal physiological functions, such as the regulation of vascular tone, cellular signalling in the brain, and elimination of pathogens (reviewed by Schmidt and Walter, 1994). Release of NO has been revealed by in vitro clumping of bacteria in the presence or absence of inhibitory drugs, or following stimulation by bacterial lipopolysaccharide (LPS) or PMA in the hemocytes of M. edulis and M. galloprovincialis (Arumugam et al., 2000a; Gourdon et al., 2001; Tafalla et al., 2002) and of Crassostrea gigas and $R$. decussatus (Arumugam et al., 2000b; Tafalla et al., 2003). NO is not toxic by itself, but in combination with super-oxide anions synthesized during phagocytosis, it generates the peroxynitrite anion (ONOO-), which is highly toxic, but extremely labile. Phagocytosisassociated peroxynitrite anion generation has been observed via chemiluminescence enhanced by bicarbonate anions in several bivalve species. Addition of yeast membrane extracts (zymosan) rapidly increases the luminescence as reported for the mussel, M. galloprovincialis (Torreilles et al., 1999). Also in M. galloprovincialis, an important increase in NO production was stimulated by human interleukin-2 but not by bacterial LPS (Novas et al., 2004). Partial inhibition by NO-synthase inhibitors demonstrated the involvement of other oxidative anions, such as peroxynitrites, the only spontaneously luminescent NO derivatives. In addition, incubation with the bacteria Vibrio tapetis induced a significant increase in NO production by R. decussatus hemocytes, but exogenous NO did not increase phagocytosis of E. coli, suggesting NO does not mediate phagocytosis in this species (Tafalla et al., 2003). Vibrio pectinicida, a pathogen to $P$. maximus larvae, was demonstrated in vitro to completely inhibit the chemiluminescence activity of adult $P$. maximus hemocytes, but only partially those of $C$. gigas (Lambert and Nicolas, 1998). Similarly, injection of $V$. anguillarum induced a reduction 
of hemocyte lysosomal membrane stability in the oyster species, C. gigas and Ostrea edulis, and in the scallop, P. maximus (Hauton et al., 2001). Live $V$. anguillarum was found to be toxic to M. edulis hemocytes in vitro, as well as bacteria-free culture supernatant (Lane and Birkbeck, 1999). There are many data demonstrating the toxic effect of bacteria on several immune-related activities in bivalves, with a clear difference between pathogenic and nonpathogenic species. Surprisingly, cannabinoid receptors have been found coupled to NO release in both $M$. edulis hemocytes and human monocytes, suggesting the opiate alkaloid signalling system has been conserved for more than 500 million years (Stefano et al., 1996).

4.4. Pro-phenoloxidase (Pro-PO) cascade. The Pro-PO system is considered to be an innate defence mechanism. Phenoloxidase (PO) activity was detected in plasma and hemocytes of several bivalves: M. edulis (Coles and Pipe, 1994), Perna viridis (Asokan et al., 1997), C. gigas, R. philippinarum, Argopecten ventricosus, Nodipecten subnodosus and Atrina maura (Hellio et al., 2007). As revealed in arthropods, PO exists as a pro-enzyme, the prophenoloxidase (pro-PO), and can be activated in vitro by exogenous proteases, detergents, laminarin or bacterial lipopolysaccharides. Based on biochemical purification the $R$. philippinarum PO was found to be a tyrosinase-type PO (Cong et al., 2005). A positive correlation was demonstrated between resistance to QX disease caused by Marteilia sydneyi, and high PO activity in Sydney rock oysters, Saccostrea glomerata (Newton et al., 2004). Furthermore, PO activity in both hemocytes and hemolymph from Tapes decussatus increased with low or medium levels of parasitisation by $P$. olseni (previously named $P$. atlanticus), but not with high levels, suggesting the influence of the parasite on this defence mechanism (Muñoz et al., 2006).

4.5. Heat shock proteins. Heat shock proteins (hsp) are constitutively expressed in cells and involved in protein folding, assembly, degradation, etc, acting as molecular chaperones. However, their over expression represents a molecular mechanism related to stress. The 
presence of specific proteins appeared in hemocytes of oysters and mussels, and in addition, the typical proteins from the hsp70 family are present also in the scallops Argopecten irradians (Song et al., 2006a) and Mizuhopecten yessoensis, and in the clam Chlamys farreri (Wu et al., 2003). Meanwhile, the Ostreidae hsp70 sequences distribute in two clearly separated clusters. As have been reported for vertebrates, the gene sequence of $M$. galloprovincialis hsp70 does not include introns (Kourtidis and Scouras, 2005). Hsp70 gene expression in M. galloprovincialis is enhanced by exposure to $30-35^{\circ} \mathrm{C}$ (Table 3) (Franzellitti and Fabbri, 2005). Surprisingly, injection of the bacteria Vibrio anguillarum also resulted in over expression of the hsp70 gene whereas no change was observed after injection of $V$. splendidus or Micrococcus lysodeikticus (Cellura et al., 2006). Interestingly, the expression of at least one protein of $45 \mathrm{kDa}$ is supressed in heat shocked hemocytes, suggesting the simultaneous existence of a down-regulation in both M. californianus and C. virginica. Based on cross-reactivity with mouse monoclonal antibodies, maximal levels of hsp72 and hsp70 were observed in M. galloprovincialis collected from the field in summer and minimal levels were found in winter (Hamer et al., 2004).

4.6. Proteases and protease-inhibitors. Extra-cellular proteins are released by the protozoan parasite, $P$. marinus, during invasion of the eastern oyster C. virginica (La Peyre et al., 1995). Such proteins, mainly proteases, can reduce in vitro hemocyte motility, lysozyme activity and hemagglutinin titres of the host, and constitute one of the weapons developed by the parasite to damage the immune defence capacities. In addition, the proteases facilitate the propagation of parasites in oysters (La Peyre et al., 1996) and might be implicated in modification of mechanisms controlling cell membrane permeability (Paynter et al., 1995). Several proteins with MW in the 40-60 kDa range belonging to P. marinus have been observed in the plasma of $C$. virginica during the first few hours following injection of the parasite (Muñoz et al., 2003). Part of the molecular host-parasite war game, protease inhibitors are found in the cell- 
free hemolymph of both $C$. virginica and C. gigas: a serine protease inhibitor (serpin) of 30 kDa and a large MW $\alpha_{2}$-macroglobulin-like protein (Faisal et al., 1998). The protective role of serpins against several protozoan parasites is well known (Rosenthal, 1999). The protease inhibitory activity against the proteases of $P$. marinus is greater for $C$. gigas than for $C$. virginica, and $C$. gigas is significantly more resistant to P. marinus than C. virginica (Meyers et al., 1991). The highest protease inhibitory activities preceded parasite elimination in $C$. gigas and it was hypothesized that such inhibitory activity represents the key event in resistance to parasite infection by neutralizing the proteases secreted by the parasite (Romestand et al., 2002). Correlation between a high level of serpins and light protozoan infection among $C$. virginica populations, as well as the increase of serpins in $C$. gigas (resistant to the parasite) and not in C. virginica (the normal host), suggested the direct involvement of protease inhibitors in the oyster defence against parasites

4.7. Lysozyme. Present in numerous animals and several body fluids, lysozyme is a widely distributed anti-bacterial molecule present in numerous animals and several body fluids. In bivalves, lysozyme activity was first reported more than 30 years ago (McDade and Tripp, 1967; Cheng and Rodrick, 1974). But it was only recently that complete amino acid sequences from Tapes japonica and Chlamys islandica were released (Ito et al., 1999). Mytilus edulis, M. galloprovincialis and the four deep-sea bivalves Bathymodiolus thermophilus (East Pacific Rise), B. azoricus (Mid Atlantic Ridge), Calyptogena sp. 1 (Barbados) and Calyptogena sp. 2 (Peru tranches) cDNA sequences are now available (Bachali et al., 2002). Bivalve lysozymes belong to the invertebrate type (i-type) lysozyme family, which differs from the insect c-type lysozyme, but is similar to vertebrate c-type (Nilsen and Myrnes, 2001). Although comprising five exons (M. edulis) versus four exons (C. islandica), the boundaries of the central exon encoding the putative active domain of the enzyme correspond exactly between the two bivalve genes (Olsen et al., 2003). Three 
additional lysozymes were isolated from $M$. edulis, with different profiles of enzymatic features, reflecting multiple genes serving different functions (Xue et al., 2007). Lysozyme sequences from the oysters, C. virginica, C. gigas and Ostrea edulis, are also available. Expressed strongly in basophilic cells from digestive gland tubules, lysozyme activity was increased by injection of bacterial DNA in the mussel Hyriopsis cumingii (Hong et al., 2006) and by injection of Vibrio tapetis in R. philippinarum, but less in R. decussatus and not increase in activity was observed in Mercenaria mercenaria or C. virginica (Allam et al., 2006). Meanwhile, the site of inoculation, pallial cavity, extra pallial space or adductor muscle, appeared crucial in generating the lysozyme response. Similarly, various extracts from $P$. marinus decreased the lysozyme activity in $C$. virginica, suggesting the parasite can modulate some defence parameters (Garreis et al., 1996).

4.8. Lysosomal enzymes. In bivalve molluscs, a variety of lysosomal enzymes have been identified in both hemocytes and serum (Table 2). Increased levels of lysosomal enzymes are induced by exposure to infectious agents and their structural components (Cheng, 1986; Oubella et al., 1994). Mechanisms of hypersynthesis of lysosomal enzymes, triggered by the challenge with bacteria, have been described in Chu (1988). After phagocytosis and internalization of particles in secondary phagososmes, enzymes in phagocytic cells degrade foreign material according to the classical pathway of lysosomal digestion. Lysosomal enzymes may also be released into the extracellular medium during or after phagocytosis by hemocytes.

4.9. Cytotoxic activity. In the mussel, M. edulis, a modification of the in vitro plaque assay has been employed to demonstrate the secretion of cytolytic molecules by hemocytes (Leippe and Renwrantz, 1988). Also the Mediterranean mussel, M. galloprovincialis, contains cytotoxic activity against both vertebrate (erythrocytes and mouse tumour) and protozoan cells (Hubert et al., 1996a), while the bacterial species, E. coli and Vibrio alginolyticus, were 
not sensitive. Injection of erythrocytes stimulated the cytotoxic activity with a maximum two days post-injection, suggesting that cytotoxic molecules are involved in immune defence (Hubert et al., 1997). The activity was still present in dialyzed samples but was destroyed by heating at $45^{\circ} \mathrm{C}$. Purification of the active molecule revealed a $320 \mathrm{kDa}$ cytotoxic polymeric protein (Roch et al., 1996; Roch, 1999). Composed of three different proteins, the complex acts like perforin through a hetero-polymerization process after binding onto target cell membranes, as revealed by electron microscopy observations (Hubert et al., 1997).

4.10. Antimicrobial peptides. Antimicrobial peptides (AMP) are among the most important effectors of innate immunity, predating lymphocytes and immunoglobulins. They are quite universal, found from plants to animals, and even in bacteria (reviewed by Boman, 1995). The first antibacterial or antiviral peptide molecules reported in marine molluscs were large proteins of 56-250 kDa found in a gastropod, the sea hare, Dolabella auricularia (Kisugi et al., 1992). Several small proteins of $4 \mathrm{kDa}$ were later purified from mussel hemocyte granules (Charlet et al., 1996; Hubert et al., 1996b). Based on primary amino acid sequence homologies, mussel peptides were arranged into three families: defensins related to arthropod defensins, and mytilins and myticins which were both found to be unique. In $M$. galloprovincialis, all the peptides possess 8 cysteines arranged in specific conserved arrays (Mitta et al., 2000a). The same structure is shared by the new myticin class, myticin C, described recently in M. galloprovincialis (Pallavicini, et al., 2008). The genes encoding these proteins showed a high polymorphic variability, which was detected after construction and and screening of SSH and cDNA libraries. This varability was also observed in clam-mytilin and clam-myticin described for the first time in the clam $R$. decussatus, and detected after analysis of a SSH library (Gestal et al., 2007). Slight differences in other amino acid sequences indicated that there are several isoforms with different biological activities, which prompt the question of the target specificity for this ancestral innate defence system. In the 
oyster Crassostrea gigas, extensive biochemical studies resulted in the identification of a 23 kDa plasma protein exhibiting poor antibacterial activity (Hubert et al., 1996a). Finally, a defensin-like peptide was isolated from acidified gill extract of $C$. virginica (Seo et al., 2005). Later, a molecular biological approach revealed the presence of two isoforms of a defensinlike protein in C. gigas (Gueguen et al., 2006; Gonzalez et al., 2007). Two partial cDNA referring to putative AMP, gigasin 2 and 3, have been identified in C. gigas. Similarly, one cDNA from M. trossulus was found to be analogous to mytilin C. In addition, one incomplete gene sequence coding gigasin 2 has been released (GenBank AJ582630). Genes encoding mussel AMPs have been sequenced, revealing identical structure including four exons and three introns (Mitta et al., 2000b, GenBank EU088427). Proposed structures of defensins from M. galloprovincialis (Yang et al., 2000) and C. gigas (Gueguen et al., 2006) have been published and they appear comparable to those of arthropod defensins with an $\alpha$ helix followed by two anti-parallel $\beta$ strands linked by intra chain disulfide bonds. In naïve mussels, the 3 AMPs are present in dramatically different quantities: myticin is expressed 300-fold more than defensin and mytilin 30-fold more (Table 3). Moreover, the genes are differentially regulated according to the challenging bacteria. Vibrio anguillarum mainly increased mytilin expression, whereas Micrococcus lysodeikticus almost suppressed defensin expression and V. splendidus decreased both mytilin and myticin expression (Cellura et al., 2007). Such effects were observed immediately after challenge, lasting less than $24 \mathrm{~h}$. In contrast, oyster defensin appeared unchanged after a bacterial challenge (Gueguen et al., 2006). Surface properties are crucial in influencing $E$. coli persistence and survival within $M$. galloprovincialis hemolymph (Canesi et al., 2001). In vitro antibacterial activity of M. edulis was provoked by LPS extract in a temperature and dose-dependent manner, suggesting the involvement of hemocyte metabolism (Hernroth, 2003). 
4.11. Antiviral activities. Although no interferon-like molecule has been described from invertebrates, there have been reports of various body extracts displaying antiviral activities. For instance, antiviral activity against amphibian virus LT-1 has been described in an aqueous extract from the clam, Mya arenaria (Li and Traxler, 1972) and neutralizing activity against T3 coliphage was observed in C. gigas hemolymph (Bachère et al., 1990). Recently, fresh filtered hemolymph of adult $C$. gigas has been reported to inhibit the replication of herpes simplex virus type 1 and the replication of infectious pancreatic necrosis virus in vitro (Olicard et al., 2005). More generally, molluscan AMP also possesses antiviral activities, like the AMP of many vertebrates and insects (Chiou et al., 2002). For instance, $5 \mu \mathrm{M}$ of mussel mytilin reduced by $50 \%$ the WSSV-induced mortality in shrimp (Dupuy et al., 2004). Moreover, synthetic fragments of AMP retained the activity, opening the field for the development of new anti viral treatments. Truncated mussel defensin is still capable of preventing infection of human cells by HIV-1 in vitro (Roch et al., 2004).

4.12. Signalling molecules. Based on the existing linkage between the immune and the endocrine system in vertebrates, investigations on the presence of signalling molecules (cytokine-related) were done in bivalves. Two approaches were developed simultaneously; studies on (i) the effect of mammalian monokines on hemocytes, and (ii) an experiment that involved labelling hemocytes with antibodies against vertebrate cytokines (Hughes et al., 1990). Results indicated that recombinant human tumour necrosis factor (TNF) activated mussel hemocytes in vitro in a dose-dependent fashion and reduced the number of circulating hemocytes when injected into the mussels, the two responses being blocked by either antiTNF or anti-interleukin 1 (IL-1) antibodies (Hughes et al., 1991a). The presence of such endogenous substances was confirmed by quantification in ELISA, but still using heterologous antibodies. Similarly, transforming growth factor (TGF) and platelet-derived growth factor (PDGF) were demonstrated by immunocytochemistry in mussel phagocyte cells 
(Franchini et al., 1996). In addition, Mytilus hemocytes have been reported to produce cytokines in response to LPS (Hughes et al., 1991b). Meanwhile, no cytokine-like mediator has been isolated as a pure molecule. The only available data concerned oysters: cloning and expression analysis of putative LPS-induced TNF- $\alpha$ factor of $C$. gigas (Park et al., 2008), one complete cds related to interleukine 17 identified in C. gigas (GenBank EF190193 from 01 Jan 08) and two partial cDNA sequences in silico related to cytokines in the oyster, $C$. virginica (GenBank CD646593 and 648005 from18 Jun 03 without more recent details).

\section{Diseases and stress: complex interactions between animal, environment}

\section{and pathogen}

Invertebrates are phylogenetically assorted and have evolved an array of efficient defense strategies to protect against pathogen attack. Marine invertebrates, especially bivalves, are particularly challenged by their environment. Due to their filter-feeding habits, bivalves gather a large number of micro-organisms, which include those that can be a source of sustenance, as well as those that can be an immune challenge.

Pollutants or xenobiotics which interact with immune system components and interfere with their protective functions are referred to as immunotoxins (Wong et al., 1992). Xenobiotics can induce immune stimulation or suppression, resulting in either auto-immunity or a decrease in disease resistance (Wong et al., 1992). According to Snieszko (1974), the development of an infectious disease results from an imbalance between the host and the pathogen due to external factors (including pollutants) and/or internal factors of both protagonists (pathogen virulence, host susceptibility).

5.1. Addressing functional proteins. As in many other invertebrates, bivalves possess a suite of adhesion molecules that aid in self/non-self recognition and bind to the carbohydrate content of foreign cells. The properties of lectins and their identification roles in host defense 
are well documented in several bivalves (Bulgakov et al. 2004). In addition, other adhesion molecules, such are collagen, galectin-, integrin- and fibronectin-like proteins, have been isolated from several bivalves (Yamaura et al., 2008; Tasumi and Vasta, 2007; Terahara et al., 2006). Bivalves, like all invertebrates, seem to rely solely on the set of pattern recognition receptors (PRRs) that detect a broad range of pathogen-associated molecular patterns (PAMPs) (Janeway and Medzhitov, 2002). Such a system might enable the distinction between wide categories of pathogens, such as Gram-positive and Gram-negative bacteria.

The mechanisms underlying host defence critically depend on the presence and the appropriate concentrations of functional proteins cited before, as well as many others still unknown, that are available in appropriate quantities, within a crucial time window. These proteins are encoded by genes whose transcription is tightly coordinated by complex programmes of gene expression. Altered or defective gene regulation may not only increase the susceptibility of the host to infection but also leads to disease outbreaks in bivalves. In this way the host gene expression profiling can results in a biological threat detection system.

5.2. Gene expression technologies. A diverse range of technologies has been developed to assess the level of gene expression, ranging from the analysis of a single gene to thousands of genes simultaneously. On the basis of experimental approach, a distinction can be made between "closed" and "open" methods. Closed approaches rely on hybridization of genes of interest to complementary nucleic acids, and, therefore, genome knowledge is a prerequisite. Examples of closed approaches are Northern blot and DNA microarray studies. In contrast, open approaches are expressed sequence tag (EST) sequencing, serial analysis of gene expression (SAGE) and massively parallel signature sequencing (MPSS). The identity of transcripts is determined by matching the experimental sequence to the genomic data. For bivalve genomics, a recent and complete review of the available data has been released by Saavedra and Bachère (2006). 
Until now, despite the economic value of many bivalve species and the availability of fullgenome sequence programmes, only oysters have been selected for genome sequencing (Hedgecock et al., 2005). On the other hand, up to several thousand redundant nucleotide records are present in GenBank and cDNA microarrays of $1.7 \mathrm{kbp}$ and $6.8 \mathrm{kbp}$ size are available for mussels and oysters, respectively (Cunningham et al., 2006; Venier et al., 2006).

5.2.1. SAGE. Serial analysis of gene exressin (SAGE), is an open high-throughput expression profiling technique that allows unbiased assessment of virtually all polyadenylated transcripts in a single sample. An attractive feature of SAGE is that the technology allows new gene discovery. The drawback of SAGE is that tags are very small and it is very tricky to completely and accurately annotate them at least until the genome organism is completely sequenced. Interestingly, application of SAGE has recently expanded from expression analysis to whole genome analysis.

Combining the specificity of chromatin immune precipitation (ChIP) with the sensitivity of SAGE, allows the identification of genome signature tags defining functional genomic elements such as transcription binding sites (Impey et al. 2004; Roh et al, 2004). To our knowledge and by mining the public database for gene expression data (Gene Expression Omnibus, GEO), no classical SAGE analysis has been conducted on any mollusc. However, new sequencing equipment is being developed, which will reduce the related cost. Three clonal cluster methodologies are now on the market for mass sequencing: pyrosequencing from 454 Life Sciences system (Margulies et al. 2005), reversible terminator-based sequencing from Illumina (Brenner et al. 2000) and sequencing by ligation from Applied Biosystems (http://solid.appliedbiosystems.com). Recently a work describing parallel mass sequencing comparable to a SAGE approach, for bivalve organisms with one of these techniques has been published. The authors investigated gene-expression patterns to elucidate growth heterosis in the Pacific oyster (C. gigas) by generating 8.6 million sequence tags 
(Hedgecock et al., 2007). About 350 heterosis-related candidate genes are waiting for the complete genome sequence to make further genetic or functional analysis easier.

5.2.2. Microarrays. DNA microarray technology is a closed high-throughput method that enables the measurement of a large predetermined set of known genes or sequences. In the microarray technology, DNA molecules representing specific transcripts are fixed onto a solid support, ranging from oligonucleotides to complete cDNAs. Inherent to closed approaches like microarray, a finite collection of arrayed sequences can be analysed. A major advantage of DNA microarrays is the commercialization of the most labour intensive parts of the methodology: collecting sequences and array fabrication. Today, several companies offer services to provide as low as a single specific microarray, ready for hybridization. However, in contrast to SAGE, comparing microarray results between laboratories is hampered by the differences in the type of array used, the spotted probe sequences and the lack of standard operating procedures (SOP). Presently, microarrays that contain thousands of genes are available for only four molluscs, one of which being from oyster, one from mussel (NCBI gene expression omnibus platforms GPL3994 and GPL1799) and two from Aplysia and squid respectively.

5.2.3. EST. Expressed sequence tag sequencing from redundant, normalized, subtractive hybridized libraries has come to the forefront as a robust and relatively inexpensive method for sampling the protein encoding genes that are expressed within a tissue or in the course of physiological disturbances. To date (January 2008) about 100,000 ESTs from bivalves are stored in public databases but many thousands more will probably be released shortly. For instance, 242 genes of the zebra mussel, Dreissena polymorpha (Bultelle et al., 2002) and 258 genes of the oyster, C. gigas (Boutet et al., 2004b) have been identified following experimental exposure to various contaminants. These observations demonstrate the need for high efficiency technology and highlight the importance of proteomic approaches for studying 
of bivalve immunology. Based on EST libraries, thousands of mRNAs have been sequenced revealing the extreme diversity of the genes being expressed at a time. The first published report was on the eastern oyster, $C$. virginica, from which two EST libraries were simultaneously constructed from single animal hemocytes (363 singletons) and from 200,000 pooled embryos (286 singletons) (Jenny et al., 2002). Less than $5 \%$ of these genes were determined to be related to immune functions. Results from a similar study in C. gigas, indicate that among the 710 singletons observed in hemocytes from bacteria challenged adults, 20 might be implicated in immune functions (Gueguen et al., 2003). A study of genes expressed in response to $P$. marinus challenge, carried out in both $C$. virginica and $C$. gigas, revealed 500 singletons of which 19 were identified as being involved in immunity and cell communication. These include genes encoding toll-like receptors (TLR), metal binding proteins, and TNF receptor associated proteins (Tanguy et al., 2004). ESTs identified in $C$. gigas affected by summer mortalities revealed that only $16 \%$ may be related to immune function (Huvet et al., 2004). The EST technology applied to C. gigas mantle led to the identification of the first oyster AMP belonging to the mussel defensin family (Gueguen et al., 2006). More generally, libraries have been constructed from multiple tissue extracts. For instance, genes encoding AMP myticin, methallothionein and heat shock proteins were among the 426 singletons identified from hemolymph, gills, digestive gland, foot, adductor muscle and mantle cDNA samples from unstressed M. galloprovincialis mussels (Venier et al., 2003). EST from gill and gonad tissues of pooled adult eastern oyster $C$. virginica revealed 1,916 singletons including several heat shock proteins, stress-induced proteins and the AMP defensin (Peatman et al., 2004). EST constructed from the whole body except digestive tracts and intestines of one single adult bay scallop A. irradians irradians revealed 2,779 unique sequences, including 131 host-defense-related gene sequences, such as lectins, defensins, proteases, protease-inhibitors, heat shock proteins, antioxidants and TLR (Song et 
al., 2006b). To better investigate host/pathogen interactions, samples should be collected at the biological interface. Sample cleaning or dissection techniques may be used to prepare homogenous tissue for random sequencing assays. This methodology becomes complicated when considering finer biological interactions where bacteria or other eukaryotic pathogens may exist as intracellular parasites or somehow be intrinsically connected with the host tissue. In such cases, cDNA libraries that contain mixed genomes will presumably be sequenced. Hence, efficient and reliable computational EST classification methods are required. The canonical approach involves performing a BLAST search against genetic databases to find significant unambiguous matches that resolve the host or pathogen origin of the sequence. But the similarity of conserved sequences and the biased taxa representation in public databases decreases the reliability of the homology approach (Koski and Golding, 2001). Advanced methods for separating of host and pathogen ESTs rely on differential codon usage profiles for the various organisms (Maor et al 2003; Emmersen at al 2007).

5.3. Systems biology research. This new investigative discipline of systems biology research has emerged rapidly in recent years (Ideker et al. 2001, Kitano 2002). Genome-wide strategies will be used to generate large multi-parameter datasets including transcriptome, proteome, metabolome and comparative genome sequences. The elimination of micro-organisms by defense cells can be regarded as a complex dynamic process, involving synthesis of proteins during differentiation, migration onto sites of infection, phagocytosis and killing of microorganisms, modulation of effector cells and finally apoptosis. Understanding how such complexity is regulated can only be addressed by global systems biology approaches because the study of single or even few parameters has been unable to completely unravel it. Currently, only one study has investigated the distinct facets of the invertebrate immune response at genomic and proteomic levels using microarray technology and mass spectrometry (Stuart et al. 2007). In this study, the authors reported an integrated approach to 
define the phagosome, interactome and related networks on a Drosophila S2 embryonic hemocyte-derived cell line. Thus, researchers could effectively decipher the continuous challenge between two genomes, i.e. evolving host-pathogen interactions.

\section{Bibliography}

Abe, H., N. Yoshikawa, M. G. Sarower, and S. Okada. Physiological function and metabolism of free D-alanine in aquatic animals. Biol. Pharm. Bull., 28(9): 1571-1577 (2005).

Abollo, E., S. M. Casas, G. Ceschia, and A. Villalba. Differential diagnosis of Perkinsus species by polymerase chain reaction-restriction fragment length polymorphism assay. Mol. Cell. Probes, 20: 323-329 (2006).

Adlard, R. D., and R. J. G. Lester. Development of a diagnostic test for Mikrocytos roughleyi, the aetiological agent of Australian winter mortality of the commercial rock oyster, Saccostrea commercialis (Iredale \& Roughley). J. Fish Dis., 18: 609-614 (1995).

Alderman, D. J., and E. B. Gareth Jones. Shell disease of oysters. Fishery Invest., London, 26: 1-19 (1971).

Allam, B., C. Paillard, M. Auffret, and S. E. Ford. Effects of the pathogenic Vibrio tapetis on defence factors of susceptible and non-susceptible bivalve species: II. Cellular and biochemical changes following in vivo challenge. Fish Shellfish Immunol., 20: 384-397 (2006).

Anderson, R. S., C. S. Giam, L. E. Ray, and M. R. Tripp. Effects of environmental pollutants on immunological competency of the clam Mercenaria mercenaria: impaired bacterial clearance. Aquat. Toxicol., 1: 187-195 (1981).

Anderson, R. S. Hemocyte-derived reactive oxygen intermediate production in four bivalve mollusks. Develop. Comp. Immunol., 18: 89-96 (1994). 
Anderson, R. S. Reactive oxygen species and antimicrobial defenses of invertebrates: a bivalve model, pp. 131-139. In: Phylogenetic perspectives on the vertebrate immune system. (Beck et al., Eds.) Kluwer Academic/Plenum Publishers (2001).

Arumugam M., B. Romestand, J. Torreilles, and Ph. Roch. In vitro production of superoxide and nitric oxide (as nitrite and nitrate) by Mytilus galloprovincialis haemocytes upon incubation with PMA or laminarin or during yeast phagocytosis. Eur. J. Cell Biol., 79: 513-519 (2000a).

Arumugam, M., B. Romestand, and J. Torreilles. Nitrite released in hemocytes from Mytilus galloprovincialis, Crassostrea gigas and Ruditapes decussatus upon stimulation with phorbol myristate acetate. Aquat. Living Resour., 13: 173-177 (2000b).

Arzul, I., T. Renault, C. Lipart, and A. J. Davison. Evidence for interspecies transmission of oyster herpesvirus in marine bivalves. J. Gen. Virol., 82: 865-870 (2001).

Arzul, I., T. Renault, A. Thébault, and G. Gérard. Detection of oyster herpesvirus DNA and proteins in asymptomatic Crassostrea gigas adults. Virus Res., 84: 151-160 (2002).

Asokan, R., M. Arumugam, and P. Mullainadhan. Activation of prophenoloxidase in the plasma and haemocytes of the marine mussel Perna viridis Linnaeus. Dev. Comp. Immunol., 21: 1-212 (1997).

Aton, E, T. Renault, B. Gagnaire, H. Thomas-Guyon, C. Cognard, and N. Imbert. A flow cytometric approach to study intracellular-free Ca2+ in Crassostrea gigas haemocytes. Fish Shellfish Immunol., 20(4): 493-502 (2006).

Auffret, M., and M. Poder. Recherches sur Marteilia maurini, parasite de Mytilus edulis sur les côtes de Bretagne nord. Rev. Trav. Inst. Pêches Mar., 47: 105-109 (1983).

Auffret, M. Morphologie comparative des types hémocytaires de quelques mollusques bivalves d'intérêt commercial. PhD. Thesis, University of Brest, France. 153 pp. (1985). 
Auffret, M. Bivalve hemocyte morphology. In: Disease processes in marine bivalve molluscs. Am. Fish. Soc., Special Pub., 18: 169-177 (1989).

Bachali, S., M. Jager, A. Hassanin, F. Schoentgen, P. Jollès, A. Fiala-Medioni, and J. S. Deutsch. Phylogenetic analysis of invertebrate lysozymes and the evolution of lysozyme function. J. Mol. Evol., 54: 652-654 (2002).

Bachère, E., D. Hervio, and E. Mialhe. Luminol-dependent chemiluminescence by hemocytes of two marine bivalves, Ostrea edulis and Crassostrea gigas. Dis. Aquat. Org., 11: 173180 (1991).

Bachère, E., D. Hervio, E. Mialhe, and H. Grizel. Evidence of neutralizing activity against T3 coliphage in oyster Crassostrea gigas hemolymph. Dev. Comp. Immunol., 14: 261-268 (1990).

Balseiro, P., R. F. Conchas, J. Montes, J. Gómes-León, B. Novoa and A. Figueras. Comparison of diagnosis techniques for the protozoan parasite Bonamia ostreae in flat oyster Ostrea edulis. Aquaculture, 261: 1135-1143 (2006).

Banerjee, B. D., V. Seth, and R. S. Ahmed. Pesticide-indudec ozidative stress: perspectives and rends. Rev. Environ. Health, 16(1): 1-40 (2001).

Barbosa-Solomieu, V., L. Miossec, R. Vazquez-Juarez, F. Ascencio-Valle, and T. Renault. Diagnosis of Ostreid herpesvirus 1 in fixed paraffin-embedded archival samples using PCR and in situ hybridisation. J. Virol. Methods., 119(2): 65-72 (2004).

Barreira, L. A., S. M. Mudge, and M. J. Bebianno. Oxidative stress in the clam Ruditapes decussatus (Linnaeus, 1758) in relation to polycyclic aromatic hydrocarbon body burden. Environ Toxicol., 22(2): 203-221 (2007).

Barry, M. M., and P. P. Yevich. Incidence of gonadal cancer in the quahaug. Oncology, 26: 87-96 (1972). 
Bayne B. L., M. N. Moore, J. Widdows, D. R. Livingstone, and P. N. Salked. Measurements of the responses of individuals to environmental stress and pollution: studies with bivalve molluscs. Phil. Trans. R. Soc. Lond., 286 B: 563-581 (1979).

Berthe, F. C. J., F. Le Roux, E. Peyretaillade, P. Peyret, D. Rodriguez, M. Gouy, and C. P. Vivarès. The existence of the phylum Paramyxea Desportes and Perkins, 1990 is validated by the phylogenetic analysis of the Marteilia refringens small subunit ribosomal RNA. J. Euk. Microbiol., 47: 288-293 (2000).

Bishop, M. J. and C. H.Peterson. Direct effects of physical stress can be counteracted by indirect benefits: oyster growth on a tidal elevation gradient. Oecologia, 147(3): 426-433 (2006).

Blair, I. A. Endogenous glutathione adducts. Curr Drug Metab., 7(8): 853-872 (2006).

Bohr, V. A. Repair of oxidative DNA damage in nuclear and mitochondrial DNA, and some changes with aging in mammalian cells. Free Radic Biol Med., 32(9): 804-812 (2002).

Boman, H. G. Peptide antibiotics and their role in innate immunity. Annu. Rev. Immunol., 13: 61-92 (1995).

Bourdineaud, J. P., M. Baudrimont, P. Gonzalez, and J. L. Moreau. Challenging the model for induction of metallothionein gene expression. Biochimie., 88(11): 1787-1792 (2006).

Boutet, I., A. Tanguy, and D. Moraga. Molecular identification and expression of two nonP450 enzymes, monoamine oxidase A and flavin-containing monooxygenase 2, involved in phase I of xenobiotic biotransformation in the Pacific oyster, Crassostrea gigas. Biochim. Biophys. Acta., 1679(1): 29-36 (2004a).

Boutet, I., A. Tanguy, and D. Moraga. Response of the Pacific oyster Crassostrea gigas to hydrocarbon contamination under experimental conditions. Gene, 329: 147-157 (2004b).

Bower, S. M., S. E. McGladdery, and I. M. Price. Synopsis of infectious diseases and parasites of commercially exploited shellfish. Ann. Rev. Fish Dis., 4: 1-199 (1994). 
Bramble, L., and R. S. Anderson. Modulation of Crassostrea virginica hemocyte reactive oxygen species production by Listonella anguillarum. Dev. Comp. Immunol., 21: 337-348 (1997).

Brenner, S., M. Johnson, J. Bridgham, G. Golda, D. H. Lloyd, D. Johnson, S. Luo, S. McCurdy, M. Foy, and M. Ewan. Gene expression analysis by massively parallel signature sequencing (MPSS) on microbead arrays. Nat. Biotechnol., 18: 630-634 (2000). doi: $10.1038 / 76469$.

Buggé, D. M., H. Hégated, G. H. Wikfors, and B. Allam. Oxidative brust in hard clam (Mercenaria mercenaria) haemocytes. Fish Shellfish Immunol., 23: 188-196 (2007).

Bulgakov, A. A., K. I. Park, K. S. Choi, H. K. Lim, and M.Cho. Purification and characterisation of a lectin isolated from the Manila clam Ruditapes philippinarum in KoreaFish Shellfish Immunol., 16 (4): 487-499 (2004).

Burreson, E. M., K. S. Reece, and C. F. Dungan. Molecular, morphological, and experimental evidence support the synonymy of Perkinsus chesapeaki and Perkinsus andrewsi. J. Euk. Microbiol., 52: 258-270 (2005).

Bultelle, F., M. Panchout, F. Leboulenger, and J. M. Danger. Identification of differentially expressed genes in Dreissena polymorpha exposed to contaminants. Mar. Environ. Res., 54: 385-389 (2002).

Cadet, P, W. Zhu, K. J. Mantione, G. Baggerman, and G. B. Stefano. Cold stress alters Mytilus edulis pedal ganglia expression of mu opiate receptor transcripts determined by real-time RT-PCR and morphine levels. Brain Res. Mol. Brain Res., 99(1): 26-33 (2002).

Cajaraville, M. P., and Angulo, E. Chlamydia-like organisms in digestive and duct cells o mussels from the Basque coast. J. Invert. Pathol., 58: 381-386 (1991).

Canesi, L., G. Gallo, M. Gavioli, and C. Pruzzo. Bacteria-hemocyte interactions and phagocytosis in marine bivalves. Microsc. Res. Tech., 57: 469-476 (2002). 
Canesi, L., C. Pruzzo, R. Tarsi, and G. Gallo. Surface interactions between Escherichia coli and hemocytes of the Mediterranean mussel Mytilus galloprovincialis leading to efficient bacterial clearance. Appl. Environ. Microbiol., 67: 464-468 (2001).

Canicatti C., and Ph. Roch. Stratégies de défense immunitaires: biologie et évolution des systèmes lytiques. Edition Masson, Paris., France. 174 pp. (1993).

Canova, S, P. Degan, L. D. Peters, D. R. Livingstone, R. Voltan, and P. Venier. Tissue dose, DNA adducts, oxidative DNA damage and CYP1A-immunopositive proteins in mussels exposed to waterborne benzo[a]pyrene. Mutat. Res., 13; 399(1): 17-30 (1998).

Carballal M. J., M. C. Lopez, C. Azevedo, and A. Villalba. Enzymes involved in defense functions of hemocytes of mussel Mytilus galloprovincialis. J. Invertebr. Pathol., 70: 96105 (1997).

Carnegie, R., B. J. Barber, S. C. Culloty, A. J. Figueras, and D. L. Distel. Development of a PCR assay for detection of the oyster pathogen Bonamia ostreae and support for its inclusion in the Haplosporidia. Dis. Aquat. Org., 42: 199-206 (2000).

Carnegie, R. B., B. J. Barber, and D. L. Distel. Detection of the oyster parasite Bonamia ostreae by fluorescent in situ hybridization. Dis. Aquat. Org., 55: 247-252 (2003).

Casas, S. M., A. Villalba, and K. S. Reece. Study of perkinsosis in the carpet shell clam Tapes decussatus in Galicia (NW Spain). I. Identification of the aetiological agent and in vitro modulation of zoosporulation by temperature and salinity. Dis. Aquat. Org., 50: 51-65 (2002).

Casas, S. M., A. Grau, K. S. Reece, K. Apakupakul, C. Azevedo, and A. Villalba. Perkinsus mediterraneus n. sp. A protistan parasite of the European flat oyster Ostrea edulis (L.) from the Coast of Balearic Islands, Mediterranean Sea. Dis. Aquat. Org., 58: 231-244 (2004).

Cavalier-Smith, T. Kingdom protozoa and its 18 phyla. Microbiol. Rev., 57: 953-994 (1993). 
Chagot, D. Caractérisation morphologique et fonctionnelle des hémocytes d'Ostrea edulis et de Crassostrea gigas (mollusques bivalves). Etude in vitro de leurs intéractions avec le protozoaire Bonamia ostreae (Ascetospora). PhD. Thesis, University of Montpellier, France. 72 pp. (1989).

Cellura, C., M. Toubiana, N. Parrinello, and Ph. Roch. HSP70 gene expression in Mytilus galloprovincialis hemocytes is triggered by moderate heat shock and Vibrio anguillarum, but not by $V$. splendidus or Micrococcus lysodeikticus. Dev. Comp. Immunol., 30: 984997 (2006).

Cellura, C., M. Toubiana, N. Parrinello, and Ph. Roch. Specific expression of antimicrobial peptide and HSP70 genes in response to heat-shock and several bacterial challenges in mussels. Fish Shellfish Immunol., 22: 340-350 (2007).

Charlet, M., S. Chernysh, H. Philippe, C. Hetrut, J. Hoffmann, and P. Bulet. Innate immunity. Isolation of several cysteine-rich antimicrobial peptides from the blood of a mollusc, Mytilus edulis. J. Biol. Chem., 271: 21808-21813 (1996).

Chaty, S, F. Rodius, and P. Vasseur. A comparative study of the expression of CYP1A and CYP4 genes in aquatic invertebrate (freshwater mussel, Unio tumidus) and vertebrate (rainbow trout, Oncorhynchus mykiss). Aquat. Toxicol., 69(1): 81-94 (2004).

Cheng, T. C., and G. E. Rodrick. Identification and characterization of lysozyme from the hemolymph of the soft-shelled clam, Mya arenaria. Biol. Bull., 147: 311-320 (1974).

Cheng, T. C. Functional morphology and biochemistry of molluscan phagocytes. Ann. N. Y. Acad. Sci., 266: 343-379 (1975).

Cheng, T. C., and G. E. Rodrick. Lysosomal and other enzymes in the hemolymph of Crassostrea gigas and Mercenaria mercenaria. Comp. Biochem. Physiol., 52 B: 443-447 (1975). 
Cheng, T. C., G. E. Rodrick, D. A. Foley, and S. A. Koehler. Release of lysozyme from hemolymph cells of Mercenaria mercenaria during phagocytosis. J. Invert. Pathol., 25: 261-265 (1975).

Cheng, T. C. Specificity and the role of lysosomal hydrolases in molluscan inflammation. Int. J. Tissue React., 8: 439-445 (1986).

Cheng, T. C., and I. C. U. Downs. Intracellular acid phosphatase and lysozyme levels in subpopulations of oyster, Crassostrea virginica, hemocytes. J. Invertebr. Pathol., 52: 163167 (1988).

Cheng, T. C. Selective induction of release hydrolases from Crassostrea virginica hemocytes by certain bacteria. J. Invertebr. Pathol., 59: 179-200 (1992).

Cheung, V. V, M. H. Depledge, and A. N. Jha. An evaluation of the relative sensitivity of two marine bivalve mollusc species using the Comet assay. Mar. Environ. Res., 62: S301-305 (2006).

Chiou, P. P., C. M. Lin, L. Perez, and T. T. Chen. Effect of cecropin B and a synthetic analogue on propagation of fish viruses in vitro. Mar. Biotechnol., 4: 294-302 (2002).

Chu, F. L. E. Humoral defense factors in marine bivalves. In : Disease processes in marine bivalve molluscs. Am. Fish. Soc. Spec. Publi., 18: 178-188 (1988).

Chu, F. L. E., and J. F. La Peyre. Effect of environmental factor and parasitism on hemolymph lysozyme and protein of American oyster (Crassostrea virginica). J. Invertebr. Pathol., 54: 224-232 (1989).

Cochennec, N., F. Le Roux, F. Berthe and A. Gérard. Detection of Bonamia ostreae based on small subunit ribosomal probe. J. Invertebr. Pathol., 76: 26-32 (2000).

Cochennec-Laureau, N., K. S. Reece, F. C. J. Berthe, and P. M. Hine. Mikrocytos roughleyi taxonomic affiliation leads to the genus Bonamia (Haplosporidia). Dis. Aquat. Org., 54: 209-217 (2003). 
Comps, M., J. R. Bonami, C. Vago, and A. Campillo. Une virose de 1'huître portugaise (Crassostrea angulata). C. R. Acad. Sc. Paris., 22: 1991-1993 (1976).

Comps, M., G. Tigé, and H. Grizel. Etude ultrastructurale d'un protiste parasite de l'huître Ostrea edulis. L.C.R. Acad. Sc. Paris, 290: 383-385 (1980)

Comps, M., Y. Pichot, and E. Peyretaillade. Recherche sur Marteilia maurini n. sp. Parasite de la moule Mytilus galloprovincialis Lmk. Revue des Travaux de l'institut des Pêches Maritimes, $45: 211-214$ (1982).

Comps, M., and D. Chagot. Une parasitose nouvelle chez la palourde Ruditapes decussates L. C. R. Acad. Sc. Paris, 282: 1991-1993 (1987).

Coles, J. A., and R. K. Pipe. Phenoloxidase activity in the hemolymph and hemocytes of the marine mussel Mytilus edulis. Fish Shellfish Immunol., 4: 337-352 (1994).

Coles, J. A., S. R. Farley, and R. K. Pipe. Alteration of the immune response to the common marine mussel Mytilus edulis resulting from exposure to cadmium. Dis. Aquat. Org., 22: 59-65 (1995).

Cong, R., W. Sun, G. Liu, T. Fan, X. Meng, L. Yang, and L. Zhu. Purification and characterization of phenoloxidase from clam Ruditapes philippinarum. Fish Shellfish Immunol., 18: 61-70 (2005).

Coss, C. A, J. A. F. Robledo, G. M. Ruiz, and G. R. Vasta. Description of Perkinsus andrewsi n. sp. isolated from the Baltic clam (Macoma balthica) by characterization of the ribosomal RNA locus, and development of a species-specific PCR-based diagnostic assay. J. Eukaryot. Microbiol., 48: 52-61 (2001).

Cunningham, C., J. I. Hikima, M. J. Jenny, R. W. Chapman, G. C. Fang, C. Saski, M. L. Lundqvist, R. A. Wing, P. M. Cupit, P. S. Gross, G. W. Warr, and J. P. Tomkins. New ressources for marine genomics: bacterial artificial chromosome libraries for the Eastern 
and Pacific oysters (Crassostrea virginica and C. gigas). Mar. Biotechnol., 8: 521-533 (2006).

David E, A. Tanguy, K. Pichavant, and D. Moraga. Response of the Pacific oyster Crassostrea gigas to hypoxia exposure under experimental conditions. FEBS J., 272 (21): 5635-5652 (2005).

Davis, H. C., V. L. Loosanoff, W. H. Weston, and C. Martin. A fungus disease in clam and oyster larvae. Science, 120: 36-38 (1954).

Davison, A. J., B. L. Trus, N. Cheng, A. C. Steven, M. S. Watson, C. Cunningham, R. M. Le Deuff, and T. Renault. A novel class of herpesvirus with bivalve hosts. J. Gen. Virol., 86: $41-53(2005)$.

Day, J. M., M. E. Franklin, and B. L. Brown. Use of competitive PCR to detect and quantify Haplosporidium nelsoni infection (MSX disease) in the eastern oyster (Crassostrea virginica). Mar. Biotechnol., 2: 456-465 (2000).

De la Herrán, R., M. A. Garrido-Ramos, J. I. Navas, C. Ruíz Rejón, and M. Ruíz-Rejón. Molecular characterization of the ribosomal RNA gene region of Perkinsus atlanticus: its use in phylogenetic analysis and as a target for a molecular diagnosis. Parasitol., 120: 345$353(2000)$.

De Zwann, A. and M. Mathieu. Cellular energy metabolism in the Mytilidae: an overview. In E. Gosling (ed) The mussel Mytilus: ecology, physiology, genetics and culture. Elsevier, Amsterdam pp. 223-307 (1991).

Diaz-Enrich, M. J., J. I. Ramos-Martinez, and I. Ibarguren. Implication of guanosine 3',5'cyclic monophosphate, adenosine 3',5'-cyclic monophosphate, adenosine 5'-mono-, diand triphosphate and fructose-2,6-bisphosphate in the regulation of the glycolytic pathway in hypoxic/anoxic mussel, Mytilus galloprovincialis. Mol. Cell Biochem., 240(1-2): 111117 (2002). 
Diggles, B. K., N. Cochennec-Laureau, and P. M. Hine. Comparison of diagnostic techniques for Bonamia existiosa in New Zealand. Aquaculture., 220: 146-156 (2003).

Doyen, P., P. Vasseur, and F. Rodius. cDNA cloning and expression pattern of pi-class glutathione S-transferase in the freshwater bivalves Unio tumidus and Corbicula fluminea. Comp Biochem Physiol. C. Toxicol. Pharmacol., 140(3-4): 300-308 (2005).

Dungan, C. F., and R. M. Hamilton. Microplate ELISA assay for detection of Perkinsus marinus in oyster tissues. J. Shellfish Res., 10: 306 (1997).

Dupuy, J. W., J. R. Bonami, and Ph Roch. A synthetic antibacterial peptide from Mytilus galloprovincialis reduces mortality due to white spot syndrome virus in palaemonid shrimp. J. Fish Dis., 27: 57-64 (2004).

Dyrynda, E. A., R. K. Pipe, and N. A. Ratcliffe. Host defence mechanisms in marine invertebrate larvae. Fish Shellfish Immunol., 5: 569-580 (1995).

Emmanouil, C., T. M. Sheehan, and J. K. Chipman. Macromolecule oxidation and DNA repair in mussel (Mytilus edulis L.) gill following exposure to $\mathrm{Cd}$ and $\mathrm{Cr}(\mathrm{VI})$. Aquat Toxicol., 82(1): 27-35 (2007).

Elandalloussi, L. M., R. M. Leite, R. Afonso, P. A. Nunes, J. A. F. Robledo, G. R. Vasta, and M. L. Cancela. Development of a PCR-ELISA assay for diagnosis of Perkinsus marinus and Perkinsus atlanticus infections in bivalve molluscs. Mol. Cell. Probes., 18: 89-96 (2004).

Elston, R., E. L. Elliot, and R. R. Colwell. Conchiolin infection and surface coating Vibria: shell fragility, growth depression and mortalities in cultured oysters and clams, Crassostrea virginica, Ostrea edulis and Mercenaria mercenaria. J. Fish Dis., 5: 265-284 (1982). 
Emmersen, J., S. Rudd, H. W. Mewes, and I. V. Tetko. Separation of sequences from hostpathogen interface using triplet nucleotide frequencies. Fungal Genetics Biol., 44 (4): 231241 (2007).

Farley, C. A. Ultrastructural observations on epizootic neoplasia and lytic virus infection in bivalve mollusks. Prog. Exp. Tumor Res., 20: 283-294 (1976).

Farley, C.A., T. H. Wolf, and R. A. Elston. A long-term study of microcell disease in oysters with a description of a new genus Mikrocytos (g. n.) and two species, Mikrocytos machini (sp. n) and M.ikrocytos roughly (sp. n). Fish. Bull,, 86: 581-592 (1988).

Faisal, M., E. A. McIntyre, K. G. Adham, B. D. Tall, M. H. Kothary, and J. F. La Peyre. Evidence for the presence of protease inhibitors in eastern (Crassostrea virginica) and pacific (Crassostrea gigas) oysters. Comp. Biochem. Physiol. Part B, 121: 161-168 (1998).

Fearon, D. T., and R. M. Locksley. The instructive role of innate immunity in the acquired immune response. Science, 272: 50-54 (1996).

Feng S. Y., J. S. Feng, C. N. Burke, and L. H. Khairallah. Light and electron microscopy of the leucocytes of Crassostrea virginica (Mollusca : Pelecypoda). Z. Zellforsch., 120: 222$245(1971)$.

Feng S. Y., J. S. Feng, and T. Yamasu. Roles of Mytilus coruscus and Crassostrea gigas blood cells in defense and nutrition, pp. 31-67. In : Comp. Pathobiol, Invertebrate Immune Responses. (Bulla, L. A., and T. C. Cheng, Eds.), Plenum, London., U.K. (1977).

Figueras, A., and B. Novoa. What has been going on in Europe in bivalve pathology? Bull. Eur. Ass. Fish Pathol., 24(1): 16-21 (2004).

Figueras, A., G. Lorenzo, C. Ordás, M. Gouy, and B. Novoa. Sequence of the small subunit ribosomal RNA gene of Perkinsus atlanticus-like isolated from carpet shell clam in Galicia, Spain. Mar. Biotechnol., 2: 419-428 (2000). 
Flajnik, M. F., and L. Du Pasquier. Evolution of innate and adaptive immunity: can we draw a line? Trends Immunol., 25: 640-644 (2004).

Ford, S.E. Comparison of hemolymph proteins from resistant and susceptible oysters, Crassostrea virginica, exposed to the parasite Haplosporidium nelsoni (MSX). J. Invert. Pathol., 47: 283-294 (1986).

Ford, S. E., R. D. Barber, and E. Marks. Disseminated neoplasia in juvenile eastern oysters, Crassotrea virginica; and its relationship to the reproductive cycle. Dis. Aquat. Org., 28: 73-77 (1997).

Franchini, A., D. Kletsas, and E. Ottaviani. Immunocytochemical evidence of PDGF- and TGF-beta-like molecules in invertebrate and vertebrate immunocytes: an evolutionary approach. Histochem. J., 28: 599-605 (1996).

Franzellitti, S., and E. Fabbri. Differential HSP70 gene expression in the Mediterranean mussel exposed to various stressors. Biochem. Biophys. Res. Commun., 336: 1157-1163 (2005)

Friedman, C. S., and R. P. Hedrick. Pacific oyster nocardiosis: isolation of the bacterium and induction of laboratory infections. J. Invert. Pathol., 57: 109-120 (1991).

Friedman, C. S., J. H. Beattie, R. A. Elston, and R. P. Hedrick. Investigation of the relationship between the presence of a gram-positive bacterial infection and summer mortality of the pacific oyster Crassostrea gigas Thunberg. Aquaculture, 94: 1-15 (1991).

Friedman, C. S., R. M. Estes, N. A. Stokes, C. A. Burge, J. S. Hargove, B. J. Barber, R. A. Elston, E. M. Burreson, and K. S. Reece. Herpes virus in juvenile Pacific oysters Crassostrea gigas from Tomales Bay, California, coincides with summer mortality episodes. Dis. Aquat. Org., 63(1): 33-41 (2005). 
Frouin, H, J. Pellerin, M. Fournier, E. Pelletier, P. Richard, N. Pichaud, C. Rouleau, and F. Garnerot. Physiological effects of polycyclic aromatic hydrocarbons on soft-shell clam Mya arenaria. Aquat. Toxicol., [Epub ahead of print] (2007).

Garreis, K. A., J. F. La Peyre, and M. Faisal. The effects of Perkinsus marinus extracellular products and purified proteases on oyster defence parameters in vitro. Fish Shellfish Immunol., 6: 581-597 (1996).

Gestal, C., M. M. Costa, A. Figueras, and B. Novoa. Analysis of differentially expressed genes in response to bacterial stimulation in hemocytes of the carpet-shell clam Ruditapes decussatus: identification of new antimicrobial peptides. Gene, 406: 134-143 (2007).

Goldberg, E. D, and K. K. Bertine. Beyond the Mussel Watch--new directions for monitoring marine pollution. Sci. Total Environ., 247(2-3): 165-174 (2000).

Grizel, H., M. Comps, J. R. Bonami, F. Cousserans, J. L. Duthoit, and M. A. Le Pennec. Recherche sur l'agent de la maladie de la glande digestive de Ostrea edulis Lenné. Sci. Pêche. Bull. Inst. Pêches Marit., 240: 7-29 (1974).

Grizel, H. Etude des récentes épizooties de l'huître plate Ostrea edulis et de leur impact sur l'ostréiculture bretonne. PhD. Thesis, University of Mobtpellier, France, 145 p. (1985).

Gómez-León, J., L. Villamil, M. L. Lemos, B. Novoa, and A. Figueras. Isolation of Vibrio alginolyticus and Vibrio splendidus from aquacultured carpet shell clam (Ruditapes decussatus) larvae associated with mass mortalities. Appl. Environ. Micorb., 71(1) : 98104. (2005)

Gonzalez, M., Y. Gueguen, G. Desserre, J. de Lorgeril, B. Romestand, and E. Bachère. Molecular characterization of two isoforms of defensin from hemocytes of the oyster, Crassostrea gigas. Dev. Comp. Immunol., 31: 332-339 (2007).

Gourdon, I., M. C. Guérin, J. Torreilles, and Ph. Roch. Nitric oxide generation by hemocytes of the mussel Mytilus galloprovincialis. Nitric Oxide: Biol. Chem., 5: 1-56 (2001). 
Gueguen, Y., J. P. Cadoret, D. Flament, C. Barreau-Roumiguière, A. L. Girardot, J. Garnier, A. Hoareau, E. Bachère, and J. M. Escoubas. Immune gene discovery by expressed sequence tags generated from hemocytes of the bacteria-challenged oyster, Crassostrea gigas. Gene, 303: 139-145 (2003).

Gueguen, Y., A. Herpin, A. Aumelas, J. Garnier, J. Fievet, J. M. Escoubas, P. Bulet, M. Gonzalez, C. Lelong, P. Favrel, and E. Bachère. Characterization of a defensin from the oyster Crassostrea gigas: recombinant production, folding, solution structure, antimicrobial activities and gene expression. J. Biol. Chem., 281: 313-323 (2006).

Hauton, C., L. E. Hawkins, and S. Hutchinson. Response of haemocyte lysosomes to bacterial inoculation in the oysters Ostrea edulis L. and Crassostrea gigas (Thunberg) and the scallop Pecten maximus (L.). Fish Shellfish Immunol., 11: 143-153 (2001).

Hedgecock, D., P. M. Gaffney, P. Goulletquer, X. Guo, K. Reece, and G. W. Warr. The case for sequencing the pacific oyster genome. J. Shellfish Res., 24: 429-441 (2005).

Hedgecock, D, J. Z. Lin, S. DeCola, C. D. Haudenschild, E. Meyer, D. T. Manahan, and B. Bowen. Transcriptomic analysis of growth heterosis in larval Pacific oysters (Crassostrea gigas). Proc. Natl. Acad. Sci. U S A., 104(7): 2313-2318 (2007).

Hellio, C, A. Bado-Nilles, B. Gagnaire, T. Renault, and H. Thomas-Guyon. Demonstration of a true phenoloxidase activity and activation of a ProPO cascade in Pacific oyster, Crassostrea gigas (Thunberg) in vitro. Fish Shellfish Immunol., 22(4): 433-440 (2007).

Hernroth, B. The influence of temperature and dose on antibacterial peptide response against lipopolysaccharide in the blue mussel, Mytilus edulis. Fish Shellfish Immunol., 14: 25-37 (2003)

Hine, P. M., N. Cochennec-Laureau, and F. C. J. Berthe. Bonamia exitiosus n. sp. (Haplosporidia) infecting flat oysters Ostrea chilensis (Philippi) in New Zealand. Dis. Aquat. Org., 47: 63-72 (2001). 
Hamer, B., D. Pavicic-Hamer, W. E. G. Müller, and R. Batel. Stress-70 proteins in marine mussel Mytilus galloprovincialis as biomarkers of environmental pollution: a field study. Environ. Int., 30: 873-882 (2004).

Hoffmann, J. A., F. C. Kafatos, C. A. Janeway, and R. A. B. Ezekowitz. Phylogenetic perspectives in innate immunity. Science, 284: 1313-1318 (1999).

Hong, X. T., L. X. Xiang, and J. Z. Shao. The immunostimulating effect of bacterial genomic DNA on the innate immune responses of bivalve mussel, Hyriopsis cumingii Lea. Fish Shellfish Immunol., 21: 357-364 (2006).

Hooper C, R. Day, R. Slocombe, J. Handlinger, and K. Benkendorff. Stress and immune responses in abalone: limitations in current knowledge and investigative methods based on other models. Fish Shellfish Immunol., 22(4): 363-379 (2007).

Hubert, F., W. van der Knaap, T. Noël, and Ph. Roch. Cytotoxic and antibacterial properties of Mytilus galloprovincialis, Ostrea edulis and Crassostrea gigas (bivalve molluscs) hemolymph. Aquat. Liv. Resour., 9: 115-124 (1996a).

Hubert, F., T. Noël, and Ph. Roch. A member of the arthropod defensin family from edible Mediterranean mussels (Mytilus galloprovincialis). Eur. J. Biochem., 240: 302-306 (1996b).

Hubert, F., E. L. Cooper, and Ph. Roch. Structure and differential target sensitivity of the stimulable cytotoxic complex from hemolymph of the Mediterranean mussel Mytilus galloprovincialis. Biochim. Biophys. Acta, 1361: 29-41 (1997).

Huffman J. E., and M. R. Tripp. Cell types and hydrolic enzymes of soft shell clam (Mya arenaria) hemocytes. J. Invertebr. Pathol., 40: 68-74 (1982).

Hughes, T. K. Jr., E. M. Smith, R. Chin, P. Cadet, J. Sinisterra, M. K. Leung, M. A. Shipp, B. Scharrer, and G. B. Stefano. Interaction of immunoactive monokines (interleukin 1 and 
tumor necrosis factor) in the bivalve mollusc Mytilus edulis. Proc. Natl. Acad. Sci. USA, 87: 4426-4429 (1990).

Hughes, T. K. Jr., R. Chin, E. M. Smith, M. K. Leung, and G. B. Stefano. Similarities of signal systems in vertebrates and invertebrates: detection, action, and interactions of immunoreactive monokines in the mussel, Mytilus edulis. Adv. Neuroimmunol., 1: 59-69 (1991a).

Hughes, T. K. Jr., E. M. Smith, J. A. Barnett, R. Charles, and G. B. Stefano. LPS stimulated invertebrate hemocytes: a role for immunoreactive TNF and IL-1. Dev. Comp. Immunol., 15: 117-122 (1991b).

Huvet, A, A. Herpin, L. Degremont, Y. Labreuche, J. F. Samain, and C. Cunningham. The identification of genes from the oyster Crassostrea gigas that are differentially expressed in progeny exhibiting opposed susceptibility to summer mortality. Gene, 343(1): 211-220 (2004).

Ideker, T., T. Galitski, and L. Hood. A new approach to decoding life: Systems biology. Annual Review of Genomics and Human Genetics, 2: 343-372 (2001).

Impey, S., S. R. McCorkle, H. Cha-Molstad, J. M. Dwyer, G. S. Yochum, J. M. Boss, S. McWeeney, J. J. Dunn, G. Mandel, and R. H. Goodman. Defining the CREB regulon: A genome-wide analysis of transcription factor regulatory regions. Cell, 119 (7): 1041-1054 (2004).

Ito, Y., A. Yoshikawa, T. Hotani, S. Fukada, K. Sugimura, and T. Imoto. Amino acid sequences of lysozymes newly purified from invertebrates imply wide distribution of a novel class in the lysozyme family. Eur. J. Biochem., 259: 456-461(1999).

Itoh, N., T. Oda, T. Yomoyoshi, and K. Ogawa. Isolation and 18S ribosomal DNA gene sequences of Marteilioides chungmuensis (Paramyxea), an ovarian parasite of the Pacific oyster Crassostrea gigas. Dis. Aquat. Org., 54: 163-169 (2003). 
Janeway Jr., C. A., and R. Medzhitov. Innate immune recognition. Annual Review of Immunology, 20: 197-216 (2002).

Jenny, M. J., A. H. Ringwood, E. R. Lacy, A. J. Lewitus, J. W. Kempton, P. S. Gross, G. W. Warr, and R. W. Chapman. Potential indicators of stress response identified by expressed sequence tag analysis of hemocytes and embryos from the American oyster, Crassostrea virginica. Mar. Biotechnol., 4: 81-93 (2002).

Jenny, M. J., Chapman, R. W., Mancia, A., Chen, Y. A., McKillen, D. J., Trent, H., Lang, P., Escoubas, J. M., Bachere, E., Boulo, V., Liu, Z. J., Gross, P. S., Cunningham, C., Cupit, P. M., Tanguy, A., Guo, X., Moraga, D., Boutet, I., Huvet, A., De Guise, S., Almeida, J. S., and G. W. Warr. A cDNA microarray for Crassostrea virginica and C. gigas. Mar Biotechnol., 9(5): 577-591 (2007).

Joyner-Matos J, C. A. Downs, and D. Julian. Increased expression of stress proteins in the surf clam Donax variabilis following hydrogen sulfide exposure. Comp. Biochem. Physiol. A Mol Integr Physiol., 145(2): 245-257 (2006).

Kinne, O. Diseases of marine animals. Biologische anstalt helgoland, Humburg, Germany. 468-1038 p. (1983).

Kisugi, J., H. Ohye, H. Kamiya, and M. Yamazaki. Biopolymers from marine invertebrates. XIII. Characterization of an antibacterial protein, dolabellanin A, from the albumen gland of the sea hare, Dolabella auricularia. Chem. Pharm. Bull., 40: 1537-1539 (1992).

Kitano, H. Systems biology: A brief overview. Science, 295 (5560): 1662-1664 (2002).

Kleeman, S. N., F. Le Roux, F. Berthe, and D. Adlard. Specificity of PCR and in situ hybridization assays designed for detection of Marteilia sydneyi and M. refringens. Parasitol., 125: 131-141 (2002). 
Kondratov, R. V., V. Y. Gorbacheva, and M. P. Antoch. The role of mammalian circadian proteins in normal physiology and genotoxic stress responses. Curr Top Dev Biol., 78: $173-216(2007)$

Koski, L. B., Golding, G. B. The closest BLAST hit is often not the nearest neighbour. J. Mol. Evol., 52 (6): 540-542 (2001).

Kotob, S. I., S. M. McLaughlin, P. Van Berkum, and M. Faisal. Discrimination between two Perkinsus spp. isolated from the softshell clam, Mya arenaria, by sequence analysis of two internal transcribed spacer regions and the 5.8 S ribosomal RNA gene. Parasitol., 4: 363-368 (1999).

Kourtidis, A. and Z. G. Scouras. Analysis and characterization of the transcriptional unit of a new Mytilus galloprovincialis (Mollusca: Bivalvia) hsp70 gene. DNA Sequence, 16: 36$43(2005)$.

Kurelec B., and R. C. Gupta. Biomonitoring of aquatic systems. IARC Sci Publ., (124): 36572 (1993).

Kurelec, B. The genotoxic disease syndrome. Mar. Environ. Res., 35: 341-348 (1993).

La Peyre, J. F., D.Y. Schafhauser, E. H. Rizkalla, and M. Faisal. Production of serine proteases by the oyster pathogen Perkinsus marinus (Apicomplexa) in vitro. J. Eukariot. Microbiol., 42: 544-551 (1995).

La Peyre, J. F., H. A. Yarnall, and M. Faisal. Contribution of Perkinsus marinus extracellular products in the infection of eastern oysters (Crassotrea gigas). J. Invertebr. Pathol., 68: 312-313 (1996).

Lacoste, A., S. K. Malham, A. Cueff, and S. A. Poulet. Noradrenaline modulates hemocyte reactive oxygen species production via $\beta$-adrenergic receptors in the osyter Crassostrea gigas. Dev. Comp. Immunol., 25: 285-289 (2001a). 
Lacoste, A., F. Jalabert, S. Malham, A. Cueff, F. Gelebart, C. Cordevant, M. Lange, and S. A. Poulet. A Vibrio splendidus strain is associated with summer mortality of juvenile oysters Crassostrea gigas in the Bay of Morlaix (North Brittany, France). Dis. Aquat. Org., 46(2): 139-145 (2001b).

Lambert, C., J. L. Nicolas, and V. Cilia. Vibrio pectinicida sp. nov., a pathogen scallop (Pecten maximus) larvae. Int. J. System. Bacteriol., 48: 481-487 (1998).

Lambert, C. and J. L. Nicolas. Specific inhibition of chemiluminescent activity by pathogenic vibrios in hemocytes of two marine bivalves: Pecten maximus and Crassostrea gigas. J. Invertebr. Pathol., 71: 53-63 (1998).

Lambert C., P. Soudant, G. Choquet, and C. Paillard. Measurement of Crassostrea gigas hemocytes oxidative metabolism by flow cytometry and the inhibiting capacity of pathogenic vibrios. Fish Shellfish Immunol., 15: 225-240 (2003).

Lane, E. and T. H. Birkbeck. Toxicity of bacteria towards hemocytes of Mytilus edulis. Aquat. Living Resour., 12: 343-350 (1999).

Lauckner, G. Diseases of Mollusca: Bivalvia, pp 477-963. In: Diseases of Marine Animals. (O. Kinne, Ed.). Biologishe Anstalt Helgoland, Hamburg (1983).

Le Gall, G., E. Mialhe, D. Chagot, and H. Grizel. Epizootiological study of ricketsiosis of the Saint-Jacques scallop Pecten maximus. Dis. Aquat. Org., 10: 139-145 (1991).

Leippe, M. and L. Renwrantz. Release of cytotoxic and agglutinating molecules by Mytilus hemocytes. Dev. Comp. Immunol., 12: 297-308 (1988).

Le Deuff, R. M., and T. Renault. Purification and partial genome characterization of a herpeslike virus infecting the Japanese oyster, Crassostrea gigas. J. Gen. Virol., 80: 1317-1322 (1999). 
Le Roux, F., G. Lorenzo, P. Peyret, C. Audemard, A. Figueras, C. Vivares, M. Gouy, and F. Berthe. Molecular evidence for the existence of two species of Marteilia in Europe. Journal of Eukaryotic Microbiol., 48: 449-454 (2001).

Le Roux, F., A. Goubet, F. L. Thompson, N. Faury, M. Gay, J. Swings, and D. Saulnier. Vibrio gigantis sp. nov., isolated from the haemolymph of cultured oysters (Crassostrea gigas). Int. J. Syst. Evol. Microbiol., 55: 2251-2255 (2005).

Legeay A, M. Achard-Joris, M. Baudrimont, J. C. Massabuau, and J. P. Bourdineaud. Impact of cadmium contamination and oxygenation levels on biochemical responses in the Asiatic clam Corbicula fluminea. Aquat Toxicol., 74(3): 242-153 (2005).

Li, M. F. and G. S. Traxler. Antiviral activity of aqueous clam (Mya arenaria) extract on amphibian virus (LT-1). Can. J. Microbiol., 18: 397-402 (1972).

Lipart, C. and T. Renault. Herpes-like virus detection in Crassostrea gigas spat using DIGlabelled probes. J. Virol. Methods, 101: 1-10 (2002).

Lodeiros, C., J. Bolinches, C. P. Dopazo, and A. E. Toranzo. Bacillary necrosis in hatcheries of Ostrea edulis in Spain. Aquaculture, 65: 15-29 (1987).

Lopez, C., A. Villalba, and E. Bachère. Absence of generation of active oxygen radicals coupled with phagocytosis by the hemocytes of the clam: Ruditapes decussatus. J. Invertebr. Pathol., 64: 188-192 (1994).

MacDonald, J. A., and K. B. Storey. Identification of a $115 \mathrm{kDa}$ MAP-kinase activated by freezing and anoxic stresses in the marine periwinkle, Littorina littorea. Arch. Biochem. Biophys., 450(2): 208-114 (2006).

Marigomez, I., U. Izagirre, and X. Lekube. Lysosomal enlargement in digestive cells of mussels exposed to cadmium, benzo[a]pyrene and their combination. Comp. Biochem. Physiol. C Toxicol. Pharmacol., 141(2): 188-193 (2005). 
Maloy, A. P., B. J. Barber, and K. J. Boettcher. A PCR-based diagnostic assay for the detection of Roseovarius crassostreae in Crassostrea virginica affected by juvenile oyster disease (JOD). Dis. Aquat. Org., 67(1-2): 155-162 (2005).

Maor, R., E. Kosman, R. Golobonski, P. Goodwin, and A. Sharon. PF-IND: Probability algorithm and software for separation of plant and fungal sequences. Current Genetics, 43(4): 296-302 (2003).

Margulies, M., M. Egholm, W. E. Altman, S. Attiya, J. S. Bader, L. A. Bemben, J. Berka, M. S. Braverman, Y. J. Chen, Z. Chen, S. B. Dewell, L. Du, J. M. Fierro, X. V. Gomes, B. C. Godwin, W. He, S. Helgesen, C. H. Ho, G. P. Irzyk, S. C. Jando, M. L. I. Alenquer, T. P. Jarvie, K. B. Jirage, J. B. Kim, J. R. Knight, J. R. Lanza, J. H. Leamon, S. M. Lefkowitz, M. Lei, J. Li, K. L. Lohman, H. Lu, V. B. Makhijani, K. E. McDade, M. P. McKenna, E. W. Myers, E. Nickerson, J. R. Nobile, R. Plant, B. P. Puc, M. T. Ronan, G. T. Roth, G. J. Sarkis, J. F. Simons, J. W. Simpson, M. Srinivasan, K. R. Tartaro, A. Tomasz, K. A. Vogt, G. A. Volkmer, S. H. Wang, Y. Wang, M. P. Weiner, P. Yu, R. F. Begley, and J. M. Rothberg. Genome sequencing in microfabricated high-density picolitre reactors. Nature, 437 (7057): 376-380 (2005).

Marsh, A. D., J. D. Gauthier, and G. R. Vasta. A semi-quantitative PCR assay for assessing Perkinsus marinus infections in the Eastern oyster, Crassostrea virginica. J. Parasitol., 81: 577-583 (1995).

MMcDade, J. E. and M. R. Tripp. Lysozyme in oyster mantle mucus. J. Invertebr. Pathol. 9: 581-582 (1967).

McDonagh, B., and D. Sheehan. Redox proteomics in the blue mussel Mytilus edulis: carbonylation is not a pre-requisite for ubiquitination in acute free radical-mediated oxidative stress. Aquat Toxicol., 79(4): 325-333 (2006). 
Meyers, J. A., E. M. Burreson, B. J. Barber, and R. Mann. Susceptibility of diploid and triploid pacific oysters Crassostrea gigas (Thunberg, 1793) and eastern oysters, Crassostrea virginica (Gmelin, 1791), to Perkinsus marinus. J. Shellfish Res., 10: 433437 (1991).

Mialhe, E., D. Chagot, V. Boulo, M. Comps, F. Ruano, and H. Grizel. An infection of Ruditapes decussates (Bivalvia) by Rickettsia. $2^{\text {nd }}$ International Colloquium on Pathology. Marine Aquaculture, 7-11 September, Portugal (1986).

Mitta, G., F. Vandenbulcke, and Ph. Roch. Original involvement of antimicrobial peptides in mussel innate immunity. FEBS Lett., 486: 185-190 (2000a).

Mitta, G., F. Hubert, E. A. Dyrynda, P. Boudry, and Ph. Roch. Mytilin B and MGD2, two antimicrobial peptides of marine mussels: gene structure and expression analysis. Dev. Comp. Immunol., 24: 381-393 (2000b).

Moore, M. N., and D. M. Lowe. The cytology and cytochemistry of the hemocytes of Mytilus edulis and their response to experimentally injected carbon particles. J. Invertebr. Pathol., 29: 18-30 (1977).

Moore G. A., and S. R. Gelder. Demonstration of lysosomal enzymes in hemocytes of Mercenaria mercenaria (Mollusca: Bivalvia). Trans. Am. Microsc. Soc., 104(3): 242-249 (1985).

Mortensen, S. H., B. Hjeltnes, O. Rodeseth, J. Krogsrud, and K. E. Christie. Infectious pancreatic necrosis virus, serotype $\mathrm{N} 1$, isolated from Norwegian halibut (Hippaglassus hippaglassus), turbot (Scapyhalmus maximus) and scallops (Pecten maximus). Bull. Eur. Ass. Fish Pathol., 10(2): 42-43 (1990).

Mortensen, S. H., E. Bachére, G. Le Gall, and E. Mialhe. Persistence of infectious pancreatic necrosis virus (IPNV) in scallops Pecten maximus. Dis. Aquat. Org., 12: 221-227 (1992). 
Munday, B. L., and L. Owens. Viral diseases of fish and shellfish in Australian mariculture. Fish Pathol., 33(4): 193-200 (1998).

Muñoz, P., K. Vance, and M. Gomez-Chiarri. Protease activity in the plasma of American oysters, Crassostrea virginica, experimentally infected with the protozoan parasite Perkinsus marinus. J. Parasitol., 89: 941-951 (2003).

Muñoz, P., J. Meseguer, and M. A. Esteban. Phenoloxidase activity in three commercial bivalve species. Changes due to natural infestation with Perkinsus atlanticus. Fish Shellfish Immunol., 20: 12-19 (2006).

Murell, A., S. N. Kleeman, S. C. Barker, and R. J. G. Lester. Synonyny of Perkinsus olseni Lester \& Davis, 1981 and Perkinsus atlanticus Azevedo, 1989 and an update on the phylogenetic position of the genus Perkinsus. Bull. Eur. Assoc. Fish Pathol., 22: 258-265 (2002).

Myrnes, B., and I. W. Nilsen. Glutathione S-transferase from the Icelandic scallop (Chlamys islandica): isolation and partial characterization. Comp. Biochem. Physiol. C Toxicol. Pharmacol., 144(4): 403-407 (2007).

Nevo, E. Evolution of genome-phenome diversity under environmental stress. Proc. Natl. Acad. Sci. U S A. 98(11): 6233-6240 (2001).

Newton, K., R. Peters, D. Raftos. Phenoloxidase and QX disease resistance in Sydney rock oysters (Saccostrea glomerata). Dev. Comp. Immunol., 28: 565-569 (2004).

Nilsen, I. W., and B. Myrnes. The gene of chlamysin, a marine invertebrate-type lysozyme, is organized similar to vertebrate but different from invertebrate chicken-type lysozyme genes. Gene, 269: 27-32 (2001).

Novoa, B., M. C. Ordás, and A. Figueras. Hypnospores detected by RFTM in clam (Ruditapes decussatus) tissues belong to two different protozoan organisms, Perkinsus atlanticus and Perkinsus-like organisms. Aquaculture, 209: 11-18 (2002). 
Novoa, B., P. Balseiro, and A. Figueras. Molecular detection of a haplosporidian parasite in carpet shell clam Ruditapes decussatus from Spain. Dis. Aquat. Org., 61: 89-93. (2004).

Novoa, B., D. Posada, and A. Figueras. Polymorphisms in the sequences of Marteilia internal transcribed spacer region of the ribosomal RNA genes (ITS-1) in Spain: genetic types are not related with bivalve hosts. J. Fish Dis., 28: 331-338 (2005).

Novas, A., A. Cao, R. Barcia, and J. I. Ramos-Martinez. Nitric oxide release by hemocytes of the mussel Mytilus galloprovincialis was provoked by interleukin-2 but not by lipopolysaccharide. Inter. J. Biochem. Cell Biol., 36: 390-394 (2004).

OIE. International Aquatic Animal Health Code. OIE, Paris, $7^{\text {th }}$ edition (2006).

Oubella, R., C. Paillard, P. Maes, and M. Auffret. Changes in hemolymph parameters in the Manila clam Ruditapes philippinarum (Mollusca, Bivalvia) following bacterial challenge. J. Invertebr. Pathol., 64: 33-38 (1994).

Olicard, C., T. Renault, C. Torhy, A. Benmansour, and N. Bourgougnon. Putative antiviral activity in hemolymph from adult Pacific oyster, Crassostrea gigas. Antiviral Res., 66: $147-152(2005)$.

Olsen, O. M., I. W. Nilsen, K. Sletten, and B. Myrnes. Multiple invertebrate lysozymes in blue mussel (Mytilus edulis). Comp. Biochem. Physiol., Biochem. Mol. Biol., 136: 107115 (2003).

Ordás, C., B. Novoa, and A. Figueras. Phagocytosis inhibition of clam and mussel haemocytes by Perkinsus atlanticus secretion products. Fish Shellfish Immunol., 9: 491503 (1999).

Ordás, M. C., B. Novoa, and A. Figueras. Modulation of the chemiluminescence response of mussel (M. galloprovincialis) hemocytes. Fish Shellfish Immunol., 10: 611-622 (2000).

Ortmann C. and M. K.Grieshaber. Energy metabolism and valve closure behaviour in the Asian clam Corbicula fluminea. J. Exp. Biol., 206 (Pt 22): 4167-4178 (2003). 
Oubella R., C. Paillard, P. Maes, M. Auffret. Changes in hemolymph parameters in the manila clam Ruditapes philippinarum (Mollusca, Bivalvia) following bacterial challenge. J. Invertebr. Pathol., 64: 33-38 (1994).

Paillard, C., L. Percelay, M. Le Pennec, and D. Le Picard. Origine pathogène de "l'aneau brun” chez Tapes philippinarum (Mollusque, bivalve). C. R. Acad. Sci. Paris., 309: 235241 (1989).

Paillard, C., P. MAes, and R. Oubella. Brown ring disease in clams. Ann. Rev. Fish Dis., 4: 219-240 (1994)

Paillard C., F. Leroux, and J. J. Borrego. Bacterial Disease in marine Bivalves: Review of recent studies. Trends and evolution. Aquat. Living Ress. "Special issue on diseases", 17: 477-498 (2004a).

Paillard C., B. Allam, and R. Oubella. Effects on Brown Ring Disease susceptibility and defense-related activities in clams Ruditapes philippinarum. Dis. Aquat. Org., 59: 249-262 (2004b).

Paillard C., S. Gausson, J. L. Nicolas, J. P. LE Pennec, and D. Haras. Molecular Identification of Vibrio tapetis, the causative agent of the brown ring disease of Ruditapes philippinarum. Aquaculture, 253: 25-38 (2006).

Pallavicini, A., M. M. Costa, C. Gestal, R. Dreos, A. Figueras, P. Venier, and B. Novoa. High sequence variability of myticin transcripts in haemocytes of immune-stimulated mussels suggests ancient host-pathogen interactions. Dev. Comp. Immunol., 32: 213-226 (2008).

Park, E. M., Y. O. Kim, B. O. Nam, H. J. King, W. J. Kim, S. J. Lee, I. S. Kong, and T. J. Choi. Cloning, characterization and expression analysis of the gene for a putative lipopolysaccharide-induced TNF- $\alpha$ factor of the Pacific oyster, Crassostrea gigas. Fish Shellfish Immunol., 24:11-17 (2008). 
Paynter, K. T., S. K. Pierce, and E. M. Burreson. Free amino acid levels in eastern oysters, Crassostrea virginica, infected with Perkinsus marinus. Mar. Biol., 122: 67-72 (1995).

Parry, H. E., and R. K. Pipe. Interactive effects of temperature and copper on immunocompetence and disease susceptibility in mussels (Mytilus edulis). Aquat. Toxicol., 69(4): 311-325 (2004).

Penna, M. S., M. Khan, and R. A. French. Development of a multiplex PCR for the detection of Haplosporidium nelsoni, Haplosporidium costale and Perkinsus marinus I the eastern oyster (Crassostrea virginica Gmelin, 1791). Mol. Cell. Probes, 15: 385-390 (2001).

Peatman, E. J., X. Wei, J. Feng, L. Liu, H. Kucuktas, P. Li, C. He, D. Rouse, R. Wallace, R. Dunham, and Z. Liu. Development of expressed sequence tags from Eastern oyster (Crassostrea virginica): lessons learned from previous efforts. Mar. Biotechnol., 6: S491496 (2004).

Plejdrup, J. K., V. Simonsen, C. Pertoldi, M. Schoyen, and M. Bayley. Genetic and morphological diversity in populations of Nucella lapillus (L.; neogastropoda) in response to tributyltin contamination. Ecotoxicol. Environ. Saf., 64(2): 146-154 (2006).

Perkins, F. O. Ultrastructure of sporulation in the European flat oyster pathogen Marteilia refringens. Taxonomic implications. J. Protozool., 23: 64-74 (1976).

Piano, A., P. Valbonesi, and E. Fabbri. Expression of cytoprotective proteins, heat shock protein 70 and metallothioneins, in tissues of Ostrea edulis exposed to heat and heavy metals. Cell Stress Chaperones, 9: 134-142 (2004).

Pipe R. K. Hydrolytic enzymes associated with the granular haemocytes of the marine mussel Mytilus edulis. Histochem. J., 22: 595-603 (1990).

Pipe, R. K. Generation of reactive oxygen metabolites by the hemocytes of the mussel Mytilus edulis. Dev. Comp. Immunol., 16: 111-122 (1992). 
Pipe R. K., J. A Coles, M. E. Thomas, V. U. Fossato, A. L. Pulsford. Evidence for environmentally derived immunomodulation in mussels from the Venice Lagoon. Aquat. Toxicol., 32: 59-73 (1995).

Porte C, G. Janer, L. C. Lorusso, M. Ortiz-Zarragoitia, M. P. Cajaraville, M. C. Fossi, and L. Canesi. Endocrine disruptors in marine organisms: approaches and perspectives. Comp. Biochem. Physiol. C. Toxicol. Pharmacol., 143(3): 303-315 (2006).

Prevodnik A, J. Gardestrom, K. Lilja, T. Elfwing, B. McDonagh, N. Petrovic, M. Tedengren, D. Sheehan, and T. Bollner. Oxidative stress in response to xenobiotics in the blue mussel Mytilus edulis L.: Evidence for variation along a natural salinity gradient of the Baltic Sea. Aquat Toxicol. [Epub ahead of print] (2007).

Reece, K. S., M. E. Siddall, E. M. Burreson, and J. E. Graves. Phylogenetic analysis of Perkinsus based on actin gene sequences. J. Parasitol. 83: 417-423 (1997).

Reece, K. S. and Stokes, N. A. Molecular analysis of a haplosopridian parasite from cultured New Zealand abalone Haliotis iris. Dis. Aquat. Org., 53: 61-66 (2003).

Reece, K. S., M. E. Siddall, N. A. Stokes, and E. M. Burreson. Molecular phylogeny of the Haplosporidia based on two independent gene sequences. J. Parasitol., 90: 1111-1122 (2004).

Reid H. I., P. Soudant, C. Lambert, C. Paillard, and T. H. Birkbeck. Salinity effects on immune parameters of Ruditapes philippinarum challenged with Vibrio tapetis. Dis Aquat Organ. 56(3): 249-258 (2003).

Renault, T., R. M. Le Deuff, N. Cochennec, and P. Maffart. Herpexvirus associated with mortalities among Pacific oyster, Crassostrea gigas, in France. Comparative study. Revue Méd. Vét., 145 : 735-742 (1994). 
Renault, T., R. M. Le Deuff, B. Chollet, N. Cochennec, and A. Gérard. Concomitant herpeslike virus infections in hatchery-reared larvae and nursery-cultured spat Crassostrea gigas, Ostrea edulis. Dis. Aquat. Org., 42:173-183 (2000).

Renault, T. and I. Arzul. Herpes-like virus infections in hatchery-reared bivalve larvae in Europe: specific viral DNA detection by PCR. J. Fish Dis. 24: 161-167 (2001).

Renault, T., C. Lipart, and I. Arzul. A herpes-like virus infects a non-ostreid bivalve species: virus replication in Ruditapes philippinarum larvae. Dis. Aquat. Org., 45: 1-7 (2001).

Riginos, C, and C. W. Cunningham. Local adaptation and species segregation in two mussel (Mytilus edulis x Mytilus trossulus) hybrid zones. Mol. Ecol., 14(2): 381-400 (2005).

Robledo, J. A. F., A. C. Wright, A. G. Marsh, and G. R. Vasta. Nucleotide sequence variability on the nontranscribed spacer of the rRNA locus in the oyster parasite Perkinsus marinus. J. Parasitol. 85: 650-656 (1999).

Robledo, J. A. F., C. A. Coss, and G. R. Vasta. Characterization of the ribosomal RNA locus of Perkinsus atlanticus and development of a polymerase chain reaction-based assay. J. Parasitol., 86: 827-837 (2000).

Robledo, J. A. F., P. A. Nunes, M. L. Cancela, and G. R. Vasta. Development of an in vitro clonal culture and characterization of the rRNA gene cluster of Perkinsus atlanticus, a protistan parasite of the clam Tapes decussatus. J. Eukaryot. Microbiol., 49: 414-422 (2002).

Roch, Ph., F. Hubert, W. van der Knaap, and T. Noël. Present knowledge on the molecular basis of cytotoxicity, antibacterial activity and stress response in marine bivalves. Ital. J. Zool., 63: 311-316 (1996).

Roch, Ph. Defense mechanisms and disease prevention in farmed marine invertebrates. Aquaculture, 172:125-145 (1999). 
Roch, Ph., A. Beschin, and E. Bernard. Anti-protozoa and antiviral activities of non-cytotoxic truncated and variant analogues of mussel defensin. eCAM, 1: 167-174 (2004).

Rodrick, G. E. Selective enzyme activities in Mya arenaria hemolymph. Comp. Biochem. Physiol., 62 B: 313-316 (1979).

Roh, T. Y., W. C. Ngau, K. Cui, D. Landsman, and K.Zhao. High-resolution genome-wide mapping of histone modifications Nature Biotechnology, 22 (8): 1013-1016 (2004).

Romestand, B., F. Corbier, and Ph. Roch. Protease inhibitors and haemagglutinins associated with resistance to the protozoan parasite, Perkinsus marinus, in the Pacific oyster, Crassostrea gigas. Parasitology, 125: 323-329 (2002).

Rosenthal, P. J. Proteases of protozoan parasites. Advances Parasitol., 43: 105-159 (1999).

Roy, D., J. B. Colerangle, and P. S. Kamleshwar. Is exposure to environmental or industrial endocrine disrupting oestrogen-like chemicals able to cause genomic instability? Frontiers in Bioscience, 3: 913-921 (1998).

Rutherford, S., J. R. Knapp, and P. Csermely. Hsp90 and developmental networks. Adv Exp Med Biol., 594: 190-197 (2007).

Saavedra, C., and E. Bachère. Bivalve Genomics. Aquaculture, 256: 1-14 (2006).

Sagristá, E., M. Dufort, and C. Azevedo. Ultrastructural study of the parasite, Perkinsus atlanticus (Apicomplexa), ion the clam Ruditapes philippinarum, in the Mediterranean. Sci. Mar., 60: 283-288 (1996).

Saldarriaga, J. F., M. L. McEwan, N. M. Fast, F. J. Taylor, and P. J. Keeling. Multiple protein phylogenies show that Oxyrrhis marina and Perkinsus marinus are early branches of the dinoflagellate lineage. Internat. J. System. Evol. Microbiol., 53: 355-365 (2003).

Schmidt, H. H. H. W. and U. Walter. NO at work. Cell, 78: 919-925 (1994). 
Seo, J. K., J. M. Crawford, K. L. Stone, and E. J. Noga. Purification of a novel arthropod defensin from the American oyster, Crassostrea virginica. Biochem. Biophys. Res. Commun., 338: 1998-2004 (2005).

Siddall, M. E., K. S. Reece, J. E. Graves and E. M. Burreson. Total evidence refutes the inclusion of Perkinsus species in the phylum Apicomplexa. Parasitol., 115: 165-176 (1997).

Sidermann, C. J. Principal Diseases of Marine fish and Shellfish; Academic Press, Inc., San Diego (1990).

Silverstein, S. C. Phagocytosis of microbes: insights and prospects. Trends Cell Biol., 5: 141$142(1995)$.

Snieszko, S. F. The effects of environmental stress on outbreaks of infectious diseases of fishes. J. Fish Biol., 6: 97-208 (1974).

Snyder, M. J., E. Girvetz, and E. P. Mulder. Induction of marine mollusc stress proteins by chemical or physical stress. Arch Environ Contam Toxicol., 41(1): 22-29 (2001).

Song, L., L. Wu, D. Ni, Y. Chang, W. Xu, and K. Xing. The cDNA cloning and mRNA expression of heat shock protein 70 gene in the haemocytes of bay scallop (Argopecten irradians, Lamarck 1819) responding to bacteria challenge and naphthalin stress. Fish Shellfish Immunol., 21: 335-345 (2006a).

Song, L., W. Xu, C. Li, H. Li, L. Wu, J. Xiang, and X. Guo. Development of expressed sequence tags from the Bay scallop Argopecten irradians irradians. Mar. Biotechnol., 8: $161-169$ (2006b).

Sprague, V. Classification of the Haplosporidia. Mar. Fish Rev., 41: 40-44 (1979). Stackebrandt, E., W. Frederiksen, G. M. Garrity, P. A. Grimont, P. Kampfer, M. C. Maiden, X. Nesme, R. Rossello-Mora, J. Swings, H. G. Truper, L. Vauterin, A. C. Ward, 
and W. B. Whitman. Report of the ad hoc committee for the re-evaluation of the species definition in bacteriology. Int. J. Syst. Evol. Microbiol., 52: 1043-1047 (2002).

Stokes, N. A. and E. M. Burreson. A sensitive and specific DNA probe for the oyster pathogen Haplosporidium nelsoni. J. Euk. Microbiol., 42: 352-357 (1995).

Stokes, N. A., M. E. Siddall, and E. M. Burreson. Detection of Haplosporidium nelsoni (Haplosporidia: Haplosporiidae) in oysters by PCR amplification. Dis. Aquat. Org., 23: 145-152 (1995).

Stokes, N. A. and E. M. Burreson. Differential diagnosis of mixed Haplosporidium costale and Haplosporidium nelsoni infections in the eastern oyster, Crassostrea virginica, using DNA probes. J. Shellfish Res., 20: 207-213 (2001).

Stefano, G. B., Y. Liu, and M. S. Gologorsky. Cannabinoid receptors are coupled to nitric oxide release in invertebrate immunocytes, microglia and human monocytes. J. Biol. Chem., 271: 19238-19242 (1996).

Stuart, L. M. and R. A. Ezekowitz. Phagocytosis: elegant complexity. Immunity, 22: 539-550 (2005).

Stuart, L. M., J. Boulais, G. M. Charriere, E. J. Hennessy, S. Brunet, I. Jutras, G. Goyette, C. Rondeau, S. Letarte, H. Huang, P. Ye, F. Morales, C. Kocks, J. S. Bader, M. Desjardins, and R. A. B. Ezekowitz. A systems biology analysis of the Drosophila phagosome. Nature, 445 (7123): 95-101 (2007).

Tafalla, C., B. Novoa, and A. Figueras. Production of nitric oxide by mussel (Mytilus galloprovincialis) hemocytes and effect of exogenous nitric oxide on phagocytic functions. Comp. Biochem. Physiol., 132: 423-431 (2002).

Tafalla, C., J. Gomez-León, B. Novoa, and A. Figueras. Nitric oxide production by carpet shell clam (Ruditapes decussatus) hemocytes. Dev. Comp. Immunol., 27: 197-205 (2003). 
Tanguy, A., C. Mura, and D. Moraga. Cloning of a metallothionein gene and characterization of two other cDNA sequences in the Pacific oyster Crassostrea gigas (CgMT1). Aquat Toxicol., 55(1-2): 35-47 (2001).

Tanguy, A., I. Boutet, F. Bonhomme, P. Boudry, and D. Moraga. Polymorphism of metallothionein genes in the Pacific oyster Crassostrea gigas as a biomarker of response to metal exposure. Biomarkers., 7(6): 439-450 (2002).

Tanguy A, X. Guo, and S. E. Ford. Discovery of genes expressed in response to Perkinsus marinus challenge in Eastern (Crassostrea virginica) and Pacific (C. gigas) oysters. Gene, 338: 121-131 (2004).

Tasumi, S., and G. R. Vasta. A Galectin of Unique Domain Organization from Hemocytes of the Eastern Oyster (Crassostrea virginica) is a Receptor for the Protistan Parasite Perkinsus marinus. J. Immunol., 179: 3086-3098 (2007).

Terahara, K., K. G. Takahashi, A. Nakamura, M. Osada, M. Yoda, T. Hiroi, M. Hirasawa, and K. Mori. Differences in integrin-dependent phagocytosis among three hemocyte subpopulations of the Pacific oyster "Crassostrea gigas". Dev. Comp. Immunol., 30: 667-683 (2006).

Thompson, F. L., Y. Li, B. Gomez-Gil, C. C. Thompson, B. Hoste, K. Vandemeulebroecke, G. S. Rupp, A. Pereira, M. M. De Bem, P. Sorgeloos, and J. Swings. Vibrio neptunius sp. nov., Vibrio brasiliensis sp. nov. and Vibrio xuii sp. nov., isolated from the marine aquaculture environment (bivalves, fish, rotifers and shrimps). Int. J. Syst. Evol. Microbiol., 53: 245-252 (2003).

Tigé, G., and M. A. Rabouin. Etude d'un lot d moules transférées dans un centre touché par l'épizootie affectant l'huitre plate. Proc. I.C.E.S., K: 1-10 (1976).

Torreilles, J., and M. C. Guérin. Production of peroxynitrite by zymosan stimulation of Mytilus galloprovincialis hemocytes in vitro. Fish Shellfish Immunol., 9: 509-518 (1999). 
Tubiash, H. S., R. R. Colwell, and R. Sakazaki. Marine vibriosis associated with bacillary necrosis, a disease of larval and juvenile bivalve molluscs. J. Bacterial., 103: 272-273 (1979).

Van Straalen N. M., and D. Roelofs. An introduction to ecological genomics. Oxford University Press, New York, pp. 307 (2006).

Valavanidis A, T. Vlahogianni, M. Dassenakis, and M. Scoullos. Molecular biomarkers of oxidative stress in aquatic organisms in relation to toxic environmental pollutants. Ecotoxicol. Environ. Saf., 64(2): 178-189 (2006).

Venier, P., A. Pallavicini, B. De Nardi, and G. Lanfranchi. Towards a catalogue of genes transcribed in multiple tissues of Mytilus galloprovincialis. Gene, 314: 29-40 (2003).

Venier, P., C. De Pitta, A. Pallavicini, F. Marsano, L. Varotto, C. Romualdi, F. Dondero, A. Viarengo, and G. Lanfranchi. Development of mussel mRNA profiling: Can gene expression trends reveal coastal water pollution?. Mutat. Res., 602(1-2): 121-134 (2006).

Vergani, L., M. Grattarola, C. Borghi, F. Dondero, and A. Viarengo. Fish and molluscan metallothioneins. FEBS J., 272(23): 6014-6023 (2005).

Villaba, A., M. J. Carballal, and C. Lopez. Disseminated neoplasia and large foci indicating heavy haemocytc infiltration in cockles Cerastoderma edule from Galicia (NS Spain). Dis. Aquat. Org., 46: 213-216 (2001).

Villalba, A., S. G. Mourelle, M. C. Lopez, M. J. Carballal, and C. Azevedo. Marteiliasis affecting cultured mussels Mytilus galloprovincialis of Galicia (NW Spain). I. Etiology, phases of the infection, and temporal and spatial variability in prevalence. Dis. Aquat. Org., 16: 61-72 (1993).

Villalba, A., K. S. Reece, M.C. Ordás, S. M. Casas, and A. Figueras. Perkinsosis in molluscs: A review. Aquat. Living Resour., 17: 411-432 (2004). 
Vivier, E., and B. Malissen. Innate and adaptive immunity: specificities and signalling hierarchies revisited. Nature Immunol., 6: 17-21 (2005).

Volety, A. K., and F. L. E. Chu. Suppression of chemiluminescence of Eastern oyster (Crassostrea virginica) hemocytes by the protozoan parasite Perkinsus marinus. Dev. Comp. Immunol., 19: 135-142 (1995).

Wintermyer, M. L., and K. R. Cooper. The development of an aquatic bivalve model: evaluating the toxic effects on gametogenesis following 2,3,7,8-tetrachlorodibenzo-pdioxin $(2,3,7,8$-TCDD) exposure in the eastern oyster (Crassostrea virginica). Aquat. Toxicol., 81(1): 10-26 (2007).

Wong, S., M. Fournier, D. Coderre, W. Banska, and K. Krzystyniak. Environmental immunotoxicology, pp. 167-189. In: Animals Biomarkers as Pollution Indicators. (Peakall, D. Ed.), Chapman and Hall, London (1992).

Wootton, E. C., and R. K. Pipe. Structural and functional characterisation of the blood cells of the bivalve mollusc, Scrobicularia plana. Fish Shellfish Immunol., 15: 249-262 (2003).

Wu, L., L. Song, W. Xu, H. Li, X. Guo, and J. Xiang. Identification and cloning of heat shock protein 70 gene from scallop, Chlamys farreri. Gaojishu Tongxun, 13: 75-79 (2003).

Xue, Q. G., N. Itoh, K. L. Schey, Y. L. Li, R. K. Cooper, and J. F. La Peyre. A new lysozyme from the eastern oyster (Crassostrea virginica) indicates adaptive evolution of i-type lysozymes. Cell. Mol. Life Sci., 64: 82-95 (2007).

Yamaura, K., K.G. Takahashi, and T. Suzuki. Identification and tissue expression analysis of C-type lectin and galectin in the Pacific oyster, Crassostrea gigas. Comparative Biochemistry and Physiology - B Biochemistry and Molecular Biology, 149: 168-175 (2008). 
Yang M, M. S. Park, and H. S. Lee. Endocrine disrupting chemicals: human exposure and health risks. J. Environ. Sci. Health C. Environ. Carcinog. Ecotoxicol. Rev., 24(2): 183224 (2006).

Yang, Y. S., G. Mitta, A. Chavanieu, B. Calas, J. F. Sanchez, Ph. Roch, and A. Aumelas. Solution structure and activity of the synthetic four-disulfide bond Mediterranean mussel defensin (MGD-1). Biochemistry, 39: 14436-14447 (2000).

Yarnal, H. A., K. S. Reece, N. A. Stokes, and E. M. Burreson. A quantitative competitive polymerase chain reaction for the oyster pathogen Perkinsus marinus. J. Parasitol., 86: 972-978 (2000).

Yoshino T. P., and T. C. Cheng. Experimentally induced elevation of aminopeptidase activity in hemolymph cells of the American oyster, Crassostrea virginica. J. Invertebr. Pathol., 27: $367-370(1976)$.

Zhang, D. D. Mechanistic studies of the Nrf2-Keap1 signaling pathway. Drug. Metab. Rev., 38(4): 769-789 (2006).

Table 1. The most serious diseases of bivalve molluscs in Europe and USA. Diversity in the pathogenic agents (viruses, bacteria, protozoan, metazoans) characterize these infectious disease.

\begin{tabular}{|l|l|l|l|l|l|}
\hline Etiology & Pathogenic agent & Disease & Host species & Economical incidence & Reference \\
\hline
\end{tabular}




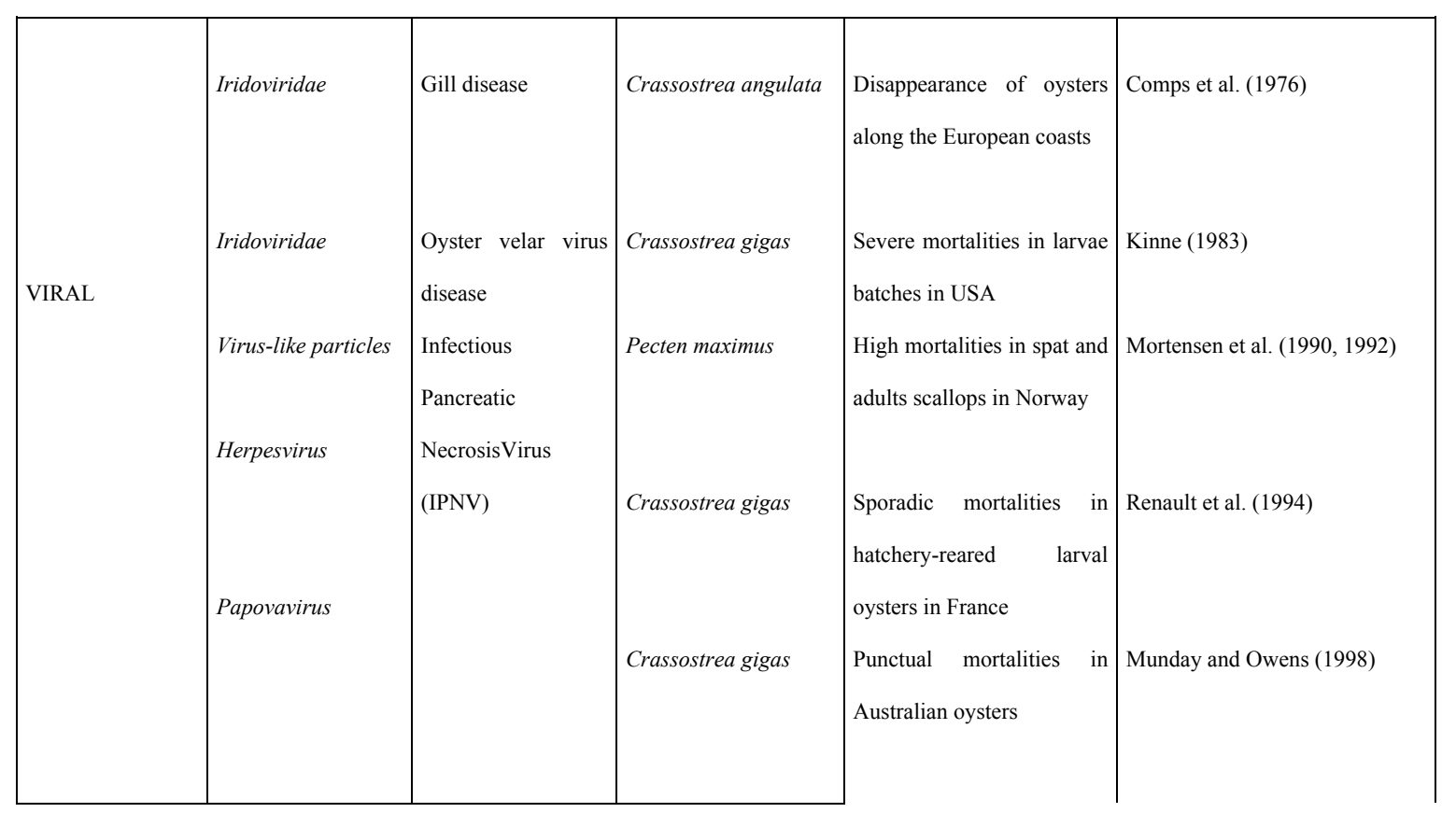




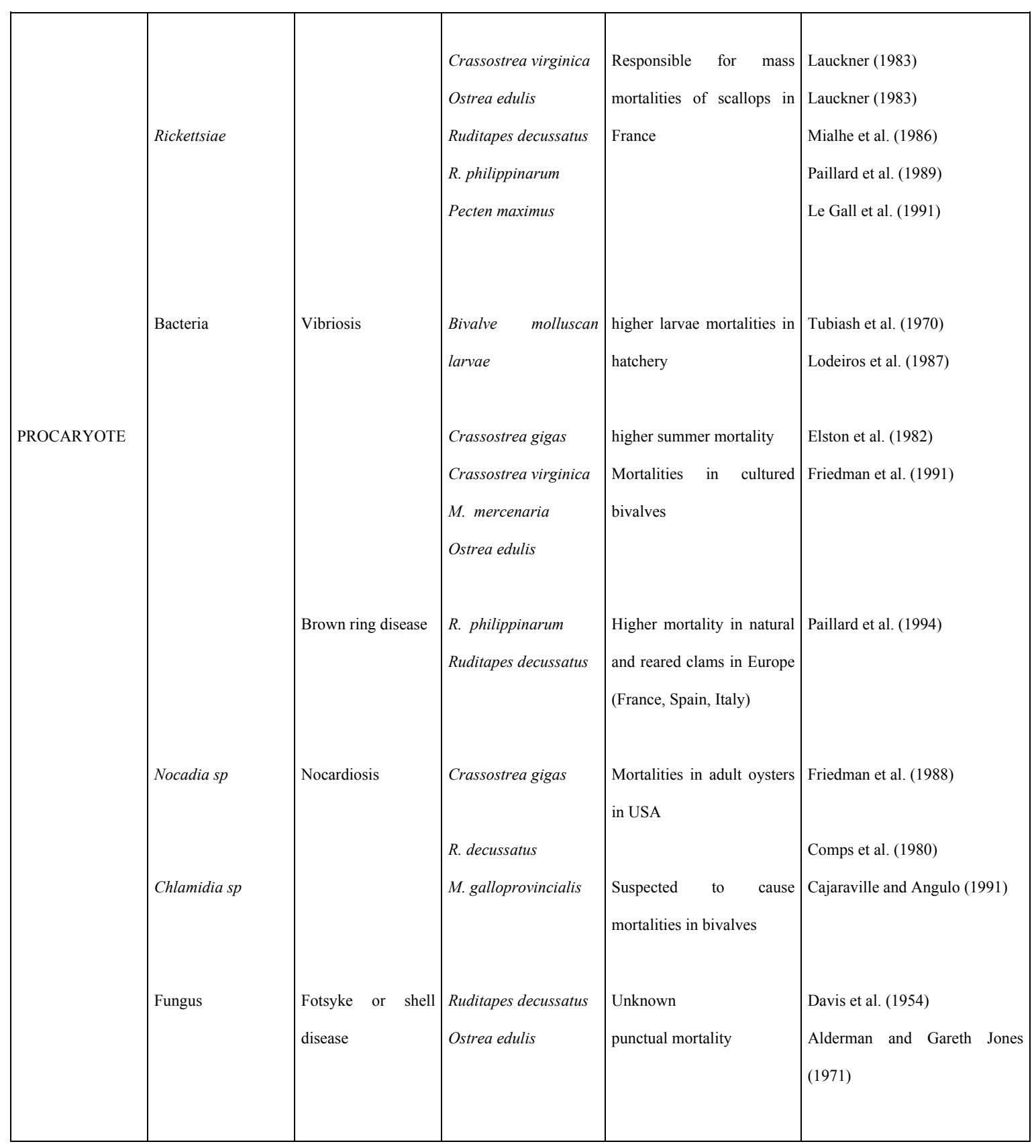




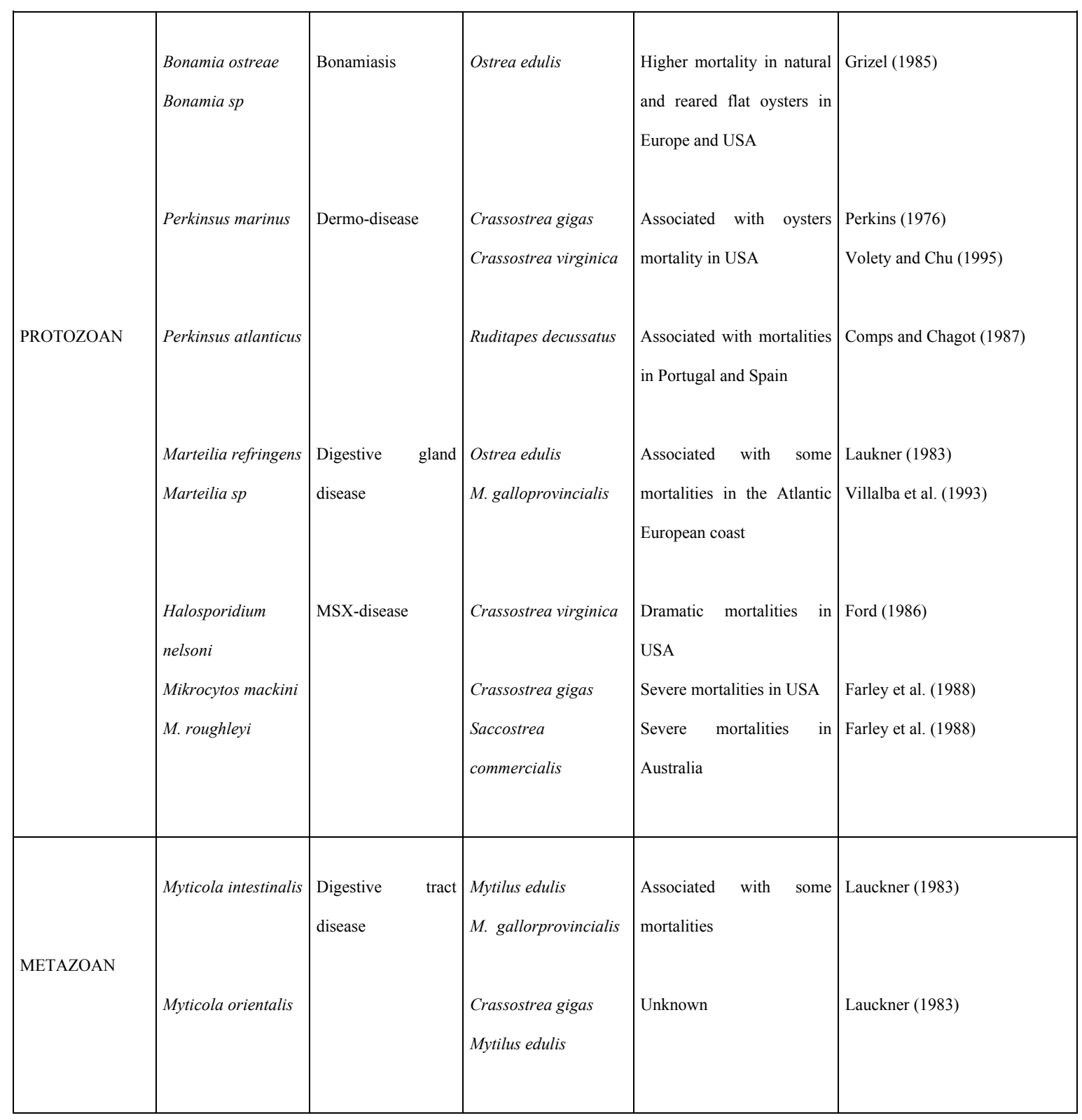


Table 2. Lysosomal enzymes and lysozyme described in some marine bivalve molluscs.

\begin{tabular}{|c|c|c|c|c|}
\hline Enzymes & Species & Origin & Biological activity & Reference \\
\hline Lysozyme & $\begin{array}{l}\text { Crassostrea virginica } \\
\text { Mercenaria mercenaria } \\
\text { Mya arenaria } \\
\text { Mytilus edulis }\end{array}$ & $\begin{array}{l}\text { Hemocytes and serum } \\
\text { Hemocytes and serum } \\
\text { Hemocytes and serum } \\
\text { tissues, hemocytes and } \\
\text { hemolymph }\end{array}$ & $\begin{array}{l}\text { bacterial lysis } \\
(\text { Gram }+)\end{array}$ & $\begin{array}{l}\text { Chu and La Peyre (1989) } \\
\text { Cheng and Rodrick (1975) } \\
\text { Cheng et al. (1975) } \\
\text { Cheng and Rodrick (1974) } \\
\text { Pipe (1990) }\end{array}$ \\
\hline Aminopeptidase & $\begin{array}{l}\text { Crassostrea virginica } \\
\text { Mercenaria mercenaria } \\
\text { Mya arenaria } \\
\text { Ruditapes philippinarum }\end{array}$ & $\begin{array}{l}\text { Hemocytes and serum } \\
\text { Hemocytes and serum } \\
\text { Hemolymph and tissues } \\
\text { Hemocytes and serum }\end{array}$ & Exopeptidase & $\begin{array}{l}\text { Cheng and Rodrick (1975) } \\
\text { Cheng and Rodrick (1975) } \\
\text { Cheng (1975) } \\
\text { Oubella et al. (1994) }\end{array}$ \\
\hline$\beta$-Glucuronidase & $\begin{array}{l}\text { Crassostrea virginica } \\
\text { Mercenaria mercenaria } \\
\text { Mya arenaria } \\
\text { Mytilus californianus } \\
\text { Mytilus edulis } \\
\text { Mytilus galloprovincialis }\end{array}$ & $\begin{array}{l}\text { Hemocytes and serum } \\
\text { Hemocytes and serum } \\
\text { Serum } \\
\text { Hemocytes } \\
\text { Hemocytes } \\
\text { Hemocytes }\end{array}$ & $\begin{array}{l}\text { Hydrolysis of the } \\
\text { mucopolysaccharides }\end{array}$ & $\begin{array}{l}\text { Moore and Gelder (1985) } \\
\text { Moore and Gelder (1985) } \\
\text { Cheng (1975) } \\
\text { Bayne et al. (1979) } \\
\text { Pipe (1990) } \\
\text { Carballal et al. (1997) }\end{array}$ \\
\hline
\end{tabular}




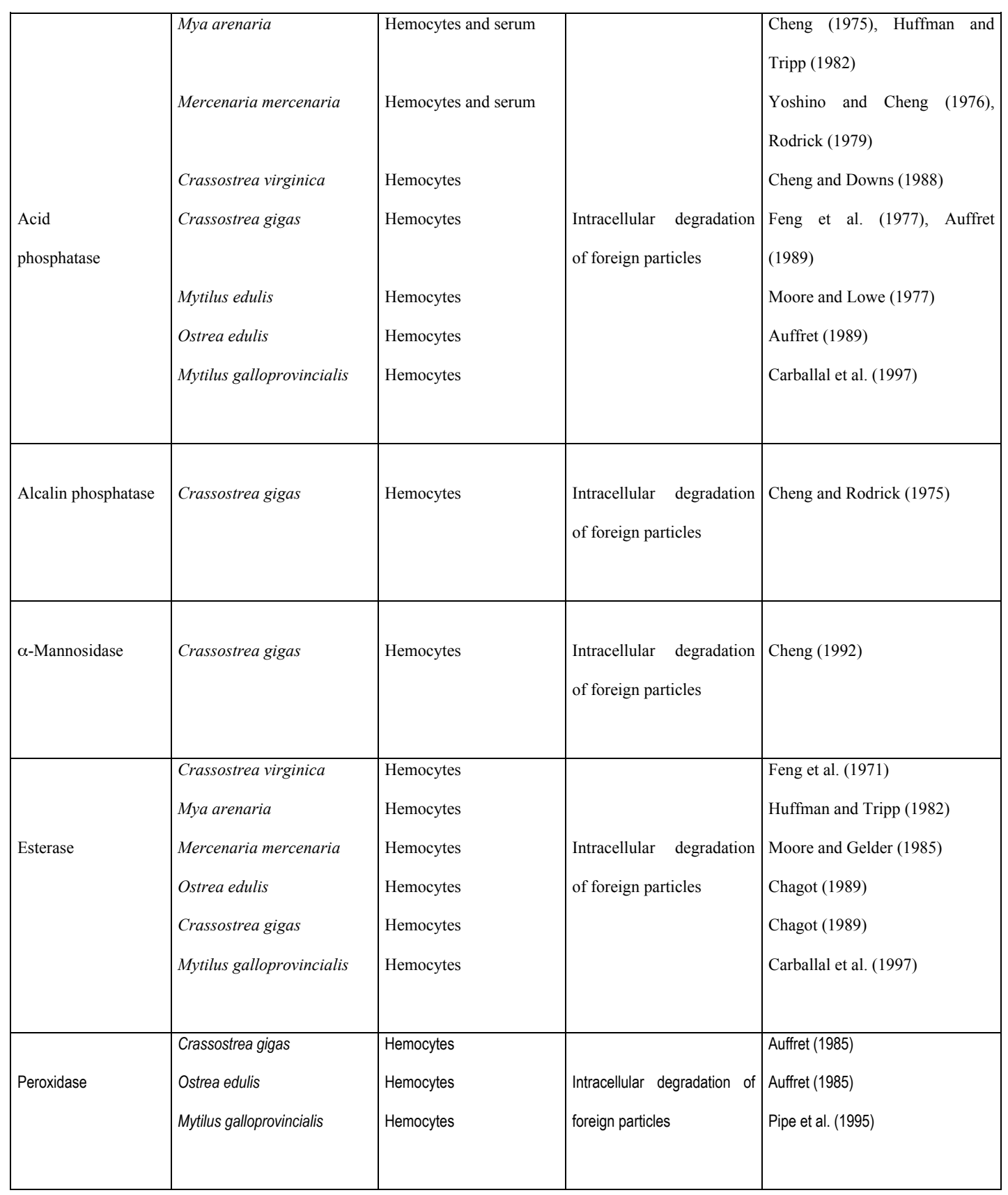


Table 3. Regulation of mussel AMP (defensin, mytilin and myticin) genes and HSP70 by bacterial injection and moderate heat shock compared to non challenged mussels expressed in relative number of mRNA copies as measured in Q-PCR, considering defensin copies in non challenged mussels as 100 (modified from Cellura et al., 2007).

\begin{tabular}{lcccc}
\hline & Defensins & Mytilins & Myticins & HSP70 \\
\hline Non challenged & 100 & 15,000 & 500,000 & 150,000 \\
$\begin{array}{l}\text { Vibrio splendidus } \\
\text { Vibrio anguillarum }\end{array}$ & 800 & 2,800 & 30,000 & 150,000 \\
$\begin{array}{l}\text { Micrococcus lysodeikticus } \\
\text { Heat shock }\end{array}$ & 100 & 150,000 & 500,000 & 850,000 \\
& 300 & 15,000 & 500,000 & 150,000 \\
& & & & \\
\end{tabular}

